\title{
Dva nepoznata dokumenta Ive Pilara iz Prvoga svjetskog rata*
}

\author{
STJEPAN MATKOVIĆ \\ Hrvatski institut za povijest \\ Zagreb, Hrvatska \\ matkovic@isp.hr \\ TOMISLAV JONJIĆ \\ Zagreb, Hrvatska \\ tomislav.jonjic@zg.t-com.hr
}

\begin{abstract}
Autori se u tekstu bave analizom dvaju novootkrivenih dokumenata koje je sastavio Ivo Pilar za potrebe informiranja visokih austrijskih krugova odlučivanja. Spomenica o novom uređenju Habsburške Monarhije i Rješenje južnoslavenskoga pitanja dio su njegovih napora da u prvoj polovici 1918. predloži promjenu dualističke strukture Austro-Ugarske i istakne rješenja u korist njegove vizije razvitka hrvatskih nacionalnih interesa. Autori navedene dokumente promatraju kroz koncepciju južnoslavenskoga pitanja koje se odnosilo na problem uređenja jugoistočnoga dijela Monarhije i na utjecaje srbijanske države. Posebnu pozornost posvećuju idejama subdualizma i kvadralizma, koje je Pilar sagledavao u kontekstu širih odnosa u Austro-Ugarskoj, napose u vezi s položajem poljskoga pitanja.
\end{abstract}

Ključne riječi: Prvi svjetski rat; hrvatska politika; Austro-Ugarska; južnoslavensko pitanje; subdualizam; kvadralizam

\section{Uvod}

O Ivi Pilaru (1874. - 1933.) već se dosta zna. Ipak, sustavna istraživanja njegova opusa još uvijek donose nova otkrića, pokazujući time njegovu svestranost i prodornost u raznim sferama djelovanja. ${ }^{1}$ Takva obilježja i dalje ga s pravom čine bitnim subjektom zanimanja povjesničara. Pilar je bio pravnik,

* Istraživanje za potrebe ovoga rada provedeno je u sklopu projekta IP-2019-04-5148 (Mappar), koji financira Hrvatska zaklada za znanost.

1 O Pilaru je napisano dosta stručnih radova, od kojih se najveći broj može naći u dvama časopisima koji su mu posvećeni: Godišnjak Pilar. Prinosi za proučavanje života i djela dra Ive Pilara i Pilar: časopis za društvene i humanističke studije. Kritički uvid u njegovu javnu karijeru, bez neprikladnih veličanja ili negacija, vidi u: JONJIĆ, „Ivo Pilar kao politički ideolog” i JONJIĆ, Ivo Pilar - pisac, političar, ideolog. 
sociolog i političar koji se okušao i na brojnim drugim kulturnim i znanstvenim područjima. Njegov politički angažman došao je do izražaja prilikom stvaranja i razvitka utjecajne Hrvatske narodne zajednice u Bosni i Hercegovini, koja je postala glavni predstavnik hrvatskoga naroda u tom okupiranom, odnosno od 1908. anektiranom području Austro-Ugarske. Premda nije bio kandidat na izborima za Bosanskohercegovački sabor niti je postao predsjednikom te kulturno-gospodarske organizacije koja je faktično prerasla u političku stranku, poput Nikole Mandića i Joze Sunarića, istraživanja pokazuju da je bio njezin ideolog i jedna od bitnih karika u održavanju njezinih političkih veza s dijelom nositelja dualističkih vlasti ili eminentnih faktora iz Beča. Zbog toga je i prije Prvoga svjetskog rata smatran za jednoga od najutjecajnijih Hrvata (katolika) u Bosni i Hercegovini. ${ }^{2}$

Nakon Sarajevskoga atentata i izbijanja rata politička je situacija zadobila novu dinamiku. Prebacivanje sukoba na vojna bojišta i suspenzija parlamentarnoga života nisu značili i zaustavljanje političkih aktivnosti. U takvim je okolnostima Pilar pokazao zavidnu pokretljivost, prerastajući među vodeće zagovornike rješavanja hrvatskoga statusa u Habsburškoj Monarhiji. To je u njegovu slučaju značilo i borbu protiv sve izraženijega jugoslavenskog pokreta, čiji su raznovrsni pristaše smatrali da se Hrvati moraju povezati s Kraljevinom Srbijom (i Crnom Gorom) te time napustiti dotadašnje državnopravno okruženje.

Pilar je ostao ponajprije zabilježen u historiografiji kao autor voluminoznoga Južnoslavenskog pitanja, knjige koja je izvorno, pod naslovom Die südslawische Frage und der Weltkrieg. Die übersichtliche Darstellung des Gesamt-Problems, tiskana u Beču tijekom ožujka 1918., nekoliko mjeseci prije sloma Austro-Ugarske. Iz te se knjige očitovalo višegodišnje Pilarovo djelovanje koje je doživjelo vrhunac tijekom Prvoga svjetskog rata, kada je postupno postalo jasno da će veliki sukob donijeti goleme posljedice za buduće odnose ne samo u Dvojnoj Monarhiji nego i u širim europskim obzorjima.

Stoga treba podsjetiti da je na početku toga rata Pilar potaknuo sarajevskoga nadbiskupa Josipa Stadlera da, poput nekih drugih katoličkih prelata, pokuša utjecati na papu Benedikta XV. ne bi li se zaustavilo uključivanje Kraljevine Italije u Prvi svjetski rat na strani Antante i time izbjegla opasnost od provedbe otprije poznatih ciljeva njezine iredentističke, odnosno imperijalističke politike. Nedugo nakon što su se ti napori pokazali neuspješnim utjecanjem na visoku međunarodnu politiku Pilar je nastavio sa svojim akcijama koje su trebale poslužiti dvama ključnim ciljevima u ratnom okruženju: povoljnijem izlaženju bečkih čimbenika moći ususret interesima Hrvata te očuvanju Austro-Ugarske kao jamstva sigurnosti njezinih lojalnih građana, a osobito očuvanju Hrvata, kojima bi, prema Pilarovu mišljenju, izvan te „veledržave" prijetile opasnosti kojima se ne bi mogli othrvati.

2 Takvim ga je ocjenjivao utjecajni general Moritz von Auffenberg, koji je 1909./10. bio zapovjednik XV. vojnoga zbora sa sjedištem u Sarajevu. Vidi: KAPIDŽIĆ, „Dva priloga novijoj istoriji Bosne i Hercegovine", 304. 
U tom je kontekstu objavio knjižicu Svjetski rat i Hrvati. Pokus orientacije hrvatskoga naroda, koja je objavljena još tijekom rata u dva izdanja (1915. te 1917.), dajući čitateljima do znanja koji su geopolitički razlozi zbog kojih se Hrvati trebaju zalagati za opstanak Monarhije. Za razliku od niza kasnijih tekstova, u toj se brošuri Pilar nije upuštao u iznošenje konkretnih prijedloga o poboljšanju hrvatskoga položaja odnosno rješenju hrvatskoga pitanja. Kako je knjiga bila namijenjena hrvatskim čitateljima, očito je smatrao da je dovoljno upozoriti na prijetnje koje izviru iz osvajačkih aspiracija susjednih država. Drugačije je postupao prema nehrvatskim, osobito prema vladajućim čimbenicima. Pred njih je stavljao i svoje konkretne prijedloge za rješenje hrvatskoga pitanja, pa je u razdoblju do objavljivanja Južnoslavenskoga pitanja, kao i u samoj toj knjizi te malo nakon njezina izlaska iz tiska izradio i više dokumenata koji su trebali poslužiti kao prijedlozi ključnim faktorima Monarhije prilikom njihova sagledavanja južnoslavenskoga pitanja i hrvatskoga položaja kao njegova sastavnoga (prema njegovu mišljenju: najvažnijega) dijela. ${ }^{3}$

Uzimajući u obzir sva navedena djela i pojedine aspekte Pilarova djelovanja, očito je da se on tijekom rata prometnuo među najagilnije zagovornike rješavanja hrvatskoga pitanja u Monarhiji. Pritom je dosljedno stupao uz kritičare ideje hrvatsko-srpskoga „narodnog jedinstva”, koja je u svojoj provedbi, pod diktatom ratnih zbivanja, trebala voditi prema stvaranju neovisne jugoslavenske države pod vodstvom srpske dinastije i sa središtem u Kraljevini Srbiji. Drugim riječima, Pilar je pod legitimnim habsburškim kišobranom vidio zaštitu od ekspanzionističkih prijetnji talijanske i srpske politike, koje su tražile svoj ratni plijen. To je bio način da se spriječi provođenje Londonskoga ugovora i otklone posljedice Niške izjave srpske vlade o borbi „za oslobođenje i ujedinjenje sve naše neslobodne braće Srba, Hrvata i Slovenaca”.

U tom je pogledu bila jasna težnja za izbjegavanjem gubitka hrvatskih teritorija i urušavanja već stečenih prava. Tijekom rata se među hrvatskim političarima javlja niz inicijativa koje idu tome u prilog. Kombinacije su bile brojne i u svima njima tražio se neki saveznik izvan idealnoga ili stvarnoga hrvatskog okvira. Primjerice, Hrvatsko-srpska koalicija, koja je imala većinu u Saboru, unatoč ideološkom osloncu na ideju „narodnoga jedinstva” čvrsto se držala dogovora s ugarskom vladom na bazi provedbe nagodbenoga zakona uz mogućnost obostrano prihvatljivih revizija. Neki su pak pogrešno računali da suradnja s talijanskim i srpskim vladinim i drugim predstavnicima može zaustaviti predvidljivi udarac na hrvatske interese kad je riječ o zaštiti teritorija i postignuću većih sloboda. Glavni im je cilj bilo rušenje Habsburške Monarhije. U tome krugu, koji je tražio rješenja izvan austrougarskoga sklopa, glavnu je riječ do druge polovice 1917. vodila skupina emigrantskih političara.

3 Vidi Pilarovu ostavštinu u zagrebačkoj Nacionalnoj i sveučilišnoj knjižnici: Promemoria über die Lösung der südslavischen Frage (25. 3. 1916.), NSK R 5704 a i b; Denkschrift über die südslavische Frage (28. 7. 1917.), NSK R 5708; Entwurf zu einem Memorandum (30. 6. 1918.) i Endgültiger Entwurf zu einem Memorandum (5. 8. 1918.), NSK R 5711 a i b. 
Suprotno njima, Pilar je razvijao političku akciju u krugu hrvatskih aktera u Monarhiji koji su sve karte stavili na habsburšku opciju. Riječ je o koncepciji vjernosti dinastiji (Habsburgtreu) i njezinoj državi (staatstreu) koja se već više puta primjenjivala u ranijoj povijesti, često s razočaravajućim ishodom (poput 1848./49.) jer dinastička lojalnost nije na odgovarajući način dovela do rezultata. Pilar je pritom pogrešno procijenio razvitak jer su opstanak i regeneracija Habsburške Monarhije izostali. Bez obzira na razne struje i njihove programe, priznanje načela samoodređenja za Hrvate i ravnopravniji status u budućem uređenju nakon završetka Prvoga svjetskog rata izostali su, svjedočeći tako o slabostima hrvatskoga položaja i hrvatske politike u širemu geostrateškom natjecanju.

\section{Analiza dokumenata}

\section{Izvori i pitanje autorstva}

Tijekom istraživanja gradiva u Austrijskome državnom arhivu (Österreichisches Staatsarchiv) - Općemu upravnom arhivu (Allgemeines Verwaltungsarchiv) pronašli smo dva dokumenta: Denkschrift über die Neuordnung der Habsburgischen Monarchie (Spomenica o novom uređenju Habsburške Monarhije, dalje: Spomenica) i Die Lösung der südslavischen Frage (Rješenje južnoslavenskog pitanja, dalje: Rješenje). Nijedan od njih nije dosad uočen ni korišten u literaturi.

Prvi se sastoji od dvanaest, a drugi od osam stranica strojem pisanoga teksta na njemačkome jeziku. Ti se dokumenti nalaze u osobnoj ostavštini austrijskoga političara Richarda Riedla (1865. - 1944.), od 1909. odjelnoga predstojnika Trgovačko-političkoga odjela austrijskoga Ministarstva trgovine (Sektionschef der handelspolitischen Sektion des Handelsministeriums), a tijekom rata glavnoga tajnika za ratno i prijelazno gospodarstvo (Generalkommisär für Kriegs- und Übergangswirtschaft), koja je pohranjena u sklopu Arhiva uprave. ${ }^{4}$ Riedl je bio pravnik koji je u svojoj bogatoj karijeri obavljao niz javnih dužnosti u sklopu donjoaustrijske Trgovačko-obrtničke komore i $\mathrm{u}$ austrijskome Ministarstvu trgovine. Osobito se isticao u radu austrijske delegacije koja je raspravljala s mađarskom stranom o financijskim aspektima Austro-ugarske nagodbe. U lipnju 1918. spominjao se kao kandidat dvora za mjesto nasljednika predsjednika austrijske vlade Ernsta Seidlera, što je pokazatelj njegova ugleda u najvišim političkim krugovima. ${ }^{5} \mathrm{Na}$ jednome ga je mjestu u svojem dnevniku Pilar zabilježio kao sugovornika s kojim je tijekom rata raspravljao o političkim pitanjima vezanim uz južnoslavensko pitanje,

4 AT-OeStA-AVA, Riedl, kut. 72, Bosnien, Südslawische Frage. Za kratak Riedlov životopis vidi: FILEK-WITTINGHAUSEN, „Riedl, Richard”, 143.

5 RUMPLER, Max Hussarek, 28. 
čime je potvrđen njihov kontakt, ali taj podatak ništa ne govori o intenzitetu tih veza. ${ }^{6}$

Premda tekstovi pronađeni u Riedlovoj ostavštini nisu potpisani, očito je Pilarovo autorstvo. Oba su teksta uvrštena u arhivsku kutiju koja se sastoji od tema vezanih uz „Bosnu i južnoslavensko pitanje” („Bosnien und südslawische Frage"), s time da je među njima još jedan Pilarov dokument - Promemoria über die Lösung der südslavischen Frage - koji je otprije poznat javnosti. ${ }^{7}$ Tim su materijalima dodani i izvadci iz spomenute Pilarove knjižice Svjetski rat $i$ Hrvati u prijevodu na njemački jezik. ${ }^{8} \mathrm{Ni}$ na jednom od tri spomenuta dokumenta nema potpisa autora. Međutim, na svima njima ručno je crvenom bojom upisano Pilarovo ime. S obzirom na sadržaj tekstova i način izlaganja, može se potvrditi da je doista riječ o Pilarovu autorstvu. Dokaz za to su i naknadno pronađeni nalazi iz osobnoga fonda Josepha Marije Baernreithera (1845. - 1925.), koji je pohranjen u Kućnome, dvorskom i državnom arhivu (Haus-, Hof- und Staatsarchiv) u Beču, gdje također nalazimo Pilarove promemorije identične onima koje smo susreli i kod Riedla. ${ }^{9}$

Baernreither je za vrijeme rata bio ministar bez lisnice u Clam-Martinicovoj vladi i načelnik Odsjeka za vanjska pitanja u austrijskoj delegaciji. On i predsjednik austrijske vlade dolazili su iz reda utjecajnih Nijemaca iz češkoga dijela Austrije. Pilar mu nije bio nepoznat jer ga je prije rata upoznao zanimajući se za južnoslavensko pitanje i obilazeći Bosnu i Hercegovinu. To zanimanje urodilo je knjižicom, zapravo zbirkom članaka pod naslovom Bosnische Eindrücke. Eine politische Studie, koju je u Beču 1908. objavio Manz Verlag, isti nakladnik koji će deset godina poslije objaviti Pilarovo životno djelo, a 1918. napisao je, odnosno objavio raspravu Bosnien und die Herzegowina in der vorottomanischen Zeit.

Iz Pilarova poslijeratnoga zapisa sigurno možemo utvrditi da se on 23. svibnja 1918. u Baernreitherovu stanu u Beču susreo i sa skupinom austrijskih Nijemaca, kojima je predočio svoje poglede na južnoslavensko pitanje. ${ }^{10}$ Ta „konferencija” u privatnome stanu zacijelo se zbila u kontekstu osnivanja Njemačkoga narodnog vijeća u Austriji, za što su neposredne pripreme počele u veljači 1918., a nakon što je 24. ožujka održana konferencija njemačkih vijećnika i zastupnika iz Češke, Beča, Donje Austrije, Kranjske, Koruške

\footnotetext{
6 JONJIĆ, Ivo Pilar - pisac, političar, ideolog, 571.

7 Promemoria über die Lösung der südslavischen Frage objavljena je u časopisu Pilar 1 (2006), br. 2: 110-117.

8 Auszug aus der Broschüre Svietski rat i Hrvati von Dr. Juricic, Zagreb 1915, II. Ausgabe, Seite 78 bis 80 .

9 AT-OeStA-HHStA, Baernreither, kut. 39, Die südslawische Frage und die Entstehung des Weltkrieges. Prije Prvoga svjetskog rata Baernreither je bio zastupnik u Gornjem domu i kratko vrijeme ministar trgovine u Thun-Hohensteinovoj vladi (1898.).

10 Dnevnik Ive Pilara 1914.-1918., 32-33. U konceptu pisma njemačkome konzulu u Zagrebu, datiranom 19. srpnja 1924., Pilar će navesti da se s Baernreitherom susreo 24. svibnja 1918. godine. NSK R 7983, Ostavština Ive Pilara, A 22, Dnevnik i JONJIĆ, Ivo Pilar-pisac, političar, ideolog, 615.
} 
i Primorja, ${ }^{11}$ do osnivačkoga je sastanka došlo u Beču 25. - 26. svibnja 1918. godine. ${ }^{12}$ Pilar je očigledno kontaktirao s pojedinim osobama iz toga kruga, ${ }^{13}$ a u vodstvo te njemačko-austrijske organizacije na osnivačkom je sastanku izabran i profesor Paul Samassa (1886. - 1941.), inače jaka figura Njemačke nacionalne stranke, rodom iz Ljubljane, koji je objavio veliki broj rasprava o južnoslavenskim temama, a uskoro će u tisku osvanuti i dva njegova prikaza glavnoga Pilarova djela. ${ }^{14}$

Prema podatcima iz literature može se očekivati da bi dodatna istraživanja mogla razotkriti još neke putove dolaska Pilarovih prijedloga u više bečke krugove. U svojoj biografiji Maxa baruna Hussarek-Henleina, predsjednika austrijske vlade, austrijski povjesničar Helmut Rumpler zapisao je da je ovaj u materijalima koje je naslijedio od svojega prethodnika Seidlera pronašao Pilarov nedatirani tekst Promemoria über die Lösung der südslavischen Frage. Prema Rumpleru, taj je tekst Hussareku poslužio kao osnova za prijedlog reforme koja bi prihvatila „velikohrvatski program konzervativne Stadlerove stranke i frankovačke stranke njenoga pandana u Hrvatskoj-Slavoniji”. ${ }^{15}$ Premda je riječ o nepreciznoj formulaciji koja ne odražava nijanse hrvatske političke scene, ona upućuje na struje sklone traženju rješenja uz bečku intervenciju s kojima je Pilar imao više ili manje doticaja.

Izuzevši izvore koji su neposredno vezani uz članove vlade, mogu se još istaknuti i neke od Pilarovih predratnih i ratnih veza s nekim drugim bitnim austrijskim političarima poput profesora i zastupnika u Carevinskom vijeću Josefa Redlicha (1869. - 1936.), kojega je također Karlo I. (IV.) tijekom Prvoga svjetskog rata angažirao za izradu planova o davanju širih nacionalnih autonomija. ${ }^{16}$ Kako se, razmjerno neočekivano, Pilar 1911. autorskim tekstom pojavio kao suradnik reprezentativne spomenice o 200. obljetnici austrijskoga Općega građanskog zakonika (Festschrift zur Jahrhundertfeier des Allgemeinen Bürgerlichen Gesetzbuches. 1. Juni 1911), ${ }^{17}$ smije se pretpostaviti da je raz-

11 „Volksratstagung in Wien”, Fremden-Blatt (Karlovy Vary), 26. 3. 1918., 6; „Deutschösterreich und die Lösung der sudslawischen Frage", Pester Lloyd. Abendblatt (Budimpešta), 27. 3. 1918., 4.

12 „Gründung eines deutschen Volksrates für Oesterreich”, Neue Freie Presse (Beč), 27. 5. 1918., 4; „Gründung eines deutschen Volksrates für Oesterreich”, Neues Wiener Tagblatt (Beč), 27. 5. 1918., 4.

13 Očigledno nije slučajno da je 24. ožujka 1918., usporedno s održavanjem konferencije austrijsko-njemačkih zastupnika i vijećnika kojoj je prva točka bilo upravo južnoslavensko pitanje - o kojem je referirao Paul Samassa - u bečkome Fremden-Blattu (24. 3. 1918., 5), listu bliskom njemačkim nacionalima, pod naslovom „Die Südslavische Frage” prikazana opsežna Pilarova knjiga izišla jedva tjedan prije.

14 JONJIĆ, Ivo Pilar - pisac, političar, ideolog, 615.

15 RUMPLER, Max Hussarek, 94.

16 FELLNER, Das politische Tagebuch Josef Redlich, sv. 2, 255 i JONJIĆ, Ivo Pilar - pisac, političar, ideolog, 570, 705.

17 PILAR, „Entwicklungsgang der Rezeption des österreichischen allgemeinen bürgerlichen Gesetzbuches in Bosnien und der Herzegowina unter besonderer Berücksichtigung des Immobilienrechtes" (objavljeno i u: Pilar 7 /2012/, br. 13 /1/: 127-148). 
granate veze imao i u pravničkim krugovima. U ratu je pak, kao što je spomenuto, uspostavio kontakt i sa Samassom, a tijekom listopada 1918. održao je dva predavanja u Austrijskom političkom društvu o južnoslavenskom pitanju. Opširni i pozitivni prikazi njegove knjige u Danzer's Armee Zeitungu te Armeeblattu sugeriraju da su postojale stanovite njegove veze i s dijelom vojnih krugova, donekle zahvaljujući i poznanstvima njegova punca Adalberta pl. Sheka, ${ }^{18}$ a ne smije se isključiti ni mogućnost da je u njima posredovao i zemaljski poglavar barun Stjepan Sarkotić, koji je u završnoj fazi rata s Pilarom dijelio niz političkih pogleda. Konačno, Pilar je imao priliku iznijeti svoje stavove i u bečkim audijencijama. Utvrđeni su susreti s ministrom predsjednikom Karlom von Stürgkhom, ugarskim ministrom predsjednikom Istvánom Tiszom, a najpoznatija je bila audijencija kod vladara - Karlo I. (IV.) primio ga je 17. kolovoza 1917. zajedno s Josipom Vancašem. Vladarevu je uredu četiri dana prije predao memorandum u kojem je predložio projekt promjena poznat pod imenom Spomenica o južnoslavenskom pitanju. ${ }^{19}$

Iz svega navedenog može se zaključiti da su Pilarovi prijedlozi tijekom rata dospjeli do dijela istaknutih austrijskih političara koji su se, pretresajući položaj raznih nacionalnih skupina, bavili i hrvatskim slučajem ne bi li na taj način dobili jasniji uvid u mogućnosti razrješavanja unutarmonarhijskih napetosti temeljenih na nacionalnome nezadovoljstvu. Pilar je izgradio svoj ugled prije Prvoga svjetskog rata. Od aneksije Bosne i Hercegovine do Sarajevskoga atentata uspostavio je korisne kontakte. Ne treba zaobići ni činjenicu da je, kao što je spomenuto, bio zet Adalberta pl. Sheka, visokoga sudskog službenika i državnoga dužnosnika koji je već slijedom svojega položaja i osobnoga raspoloženja znao razviti veze s bitnim čimbenicima u državnom vrhu. U ratu je Pilar radi ostvarenja svojih ciljeva posegnuo i za donekle neočekivanim taktičkim potezima, pa se povezao i s vrhbosanskim nadbiskupom Stadlerom, u čije je ime nastupao kao jedan od tumača interesa bosanskohercegovačkih Hrvata. U jednome dijelu ratnoga razdoblja surađivao je s krugom oko tzv. frankovačkih pravaša, koji su također tražili rješenje nacionalnoga pitanja u Habsburškoj Monarhiji. Međutim, komparativna analiza njihovih planova i prijedloga pokazuje koncepcijske razlike koje su očito bile uvjetovane i prethodnim Pilarovim oblikovanjem u drugačijem svjetonazorsko-ideološkom sklopu. ${ }^{20}$

18 JONJIĆ, Ivo Pilar - pisac, političar, ideolog, 610-612. Nakladnik i urednik Danzer's Armee Zeitunga i prije je pokazivao zanimanje za južnoslavensku problematiku i pitanja preuređenja Monarhije. Vidi: DANZER, Das neue Österreich, IX-XII.

19 JONJIĆ, Ivo Pilar - pisac, političar, ideolog, 677-693.

20 MATKOVIĆ, „Je li Ivo Pilar bio pravaš?”, 387-427. 


\section{Datacija}

Datiranje je prvi zadatak koji nameću novopronađeni Pilarovi dokumenti. Naime, nijedan od dva dosad nepoznata teksta iz Riedlove ostavštine, sastavljena na istome ili bar istovrsnome pisaćem stroju i konopcem uvezana u cjelinu, nema nadnevak. Jedino je kod primjerka već poznate Promemorije o rješenju južnoslavenskoga pitanja, koji se nalazi i u Riedlovu posjedu, ručno upisana 1916. godina, koja pak nameće istraživačko preispitivanje. Naime, ta se godina ne podudara s datacijom u tiskanoj inačici Promemorije. ${ }^{21}$ Međutim, u jednoj podrobnoj analizi već je objašnjeno da je Pilar operirao jednom svojom Promemorijom koja je sastavljena na njemačkome jeziku i datirana u njegovu obitavalištu u Tuzli 25. ožujka 1916., a onda je, s manjim preinakama, u ožujku ili travnju 1917. inkorporirao njezin sadržaj u rukopis Južnoslavenskoga pitanja kao dokument koji da je djelo navodnoga njemu poznatoga „privatnog učenjaka" i koji da pod izmijenjenim naslovom Denkschrift über die Lösung der kroatischen Frage "cirkulira” po jugu Monarhije. ${ }^{22}$ To bi značilo da je tekst Promemorije doista mogao biti napisan još za vrijeme vladavine Franje Josipa, da je dospio u ruke više državne birokracije u Beču i da je time pripreman teren za predaju dokumenta novome vladaru kao jedan od prijedloga za rješavanje južnoslavenskoga pitanja kojim bi se uzajamno zadovoljili interesi hrvatskoga čimbenika i načelo teritorijalnoga integriteta Monarhije. Drugim riječima, u 1916. godini možemo očitati izvorno stajalište Pilara o rješavanju hrvatskoga/južnoslavenskoga pitanja koje on zatim, ovisno o okolnostima, modificira u nizu novih dokumenata.

Kad je riječ o dvama novopronađenim dokumentima, njih se nikako ne može staviti u 1916., na što bi nas mogla navesti datacija u dijelu Riedlovih papira. Analiza njihova sadržaja traži da ih datiramo u kasnije razdoblje, najvjerojatnije u prve mjesece 1918., kad su ruski izlazak iz rata i mir u Brest-Litovsku nametnuli rješavanje poljskoga pitanja u zaoštrenijem obliku nego do tada. Zamisli o trijalističkom rješenju na sjeveru Monarhije koje su se do tada javljale, redovito nailazeći na otpor austrijsko-njemačkih i mađarskih krugova, $\mathrm{u}$ javnosti - a nesumnjivo i u političkim krugovima, koji su pored poremećaja ravnoteže između Beča i Budimpešte strahovali još i od prijepora između Berlina i Beča - postupno ustupaju mjesto ideji o subdualističkome, „austro-poljskom” rješenju. ${ }^{23}$ Proces je to koji je u nekim svojim elementi-

${ }^{21}$ Prema otisnutom prilogu, transkriptor Zoran Grijak, oslanjajući se razumljivo na izvorni podatak iz arhiva Federacije Bosne i Hercegovine, navodi u apstraktu članka pisanog na engleskom jeziku da je riječ o kolovozu 1917. („in his Promemoria from August 1917”). Vidi: Promemoria über die Lösung der südslavischen Frage, u: Pilar, 111. Tomislav Jonjić donosi još podatke da se dvije inačice Pilarove Promemorije nalaze u zagrebačkoj Nacionalnoj i sveučilišnoj knjižnici (NSK R 5704 a i NSK R 5704 b) te da je objavljena i u: ĐAKOVIĆ, Položaj Bosne i Hercegovine u austrougarskim koncepcijama. Vidi: JONJIĆ, Ivo Pilar - pisac, političar, ideolog, 622.

22 JONJIĆ, Ivo Pilar - pisac, političar, ideolog, 664-665.

23 Vidi primjerice: Julius ANDRÁSSY, „Uber die polnische Frage”, Fremden-Blatt, 11. 12. 1917., 1-2; „Polens Zukunft”, Innsbrucker Nachrichten (Innsbruck), 27. 12. 1917., 1; „Oesterre- 
ma analogan procesima na jugoistoku države, ${ }^{24}$ pa je posve logično da je kao neostvariva napuštana trijalistička ideja, a da su dva subdualizma, jedan u austrijskoj, drugi u mađarskoj polovici Monarhije, rezultirali kvadralističkom formulom. Pilar je odavno bio svjestan da je dualizam ključni uzrok slabosti hrvatskoga položaja, pa je - očito pomno prateći te državno-pravne rasprave i osluškujući raspoloženje u austrijsko-njemačkim i kršćansko-socijalnim krugovima, koje je smatrao glavnim saveznicima u borbi protiv mađarskoga hegemonizma i imperijalizma - bio jedan od rijetkih ili čak jedini Hrvat koji je prigrlio kvadralističku koncepciju kao potencijalno provedivu zamisao o rekonstrukciji Austro-Ugarske. ${ }^{25}$

Kad je riječ o prvom dokumentu, novopronađenoj Spomenici, najprije treba naglasiti da taj dokument ne valja brkati sa Spomenicom o južnoslavenskom pitanju (Denkschrift über die südslavische Frage) koja je datirana 28. srpnja 1917. i već joj je potvrđeno Pilarovo autorstvo. ${ }^{26} \mathrm{Uz}$ nominalnu razliku u naslovu, treba istaknuti da je ona već poznata i objavljena verzija opsežnija od novopronađene. Sličnost obaju dokumenta vidi se u činjenici da se u oba koristi izraz „južnoslavensko pitanje” i da se pritom iznose identični argumenti u kritici rezultata dotadašnjega dualizma, objašnjavanju vanjskih opasnosti koje prijete Monarhiji i ponudi određenih rješenja za njezinu konsolidaciju.

S druge strane, sadržaj novopronađene Spomenice upućuje na zaključak da je ona nastala najvjerojatnije u prvim mjesecima 1918., prije izlaska Južnoslavenskoga pitanja iz tiska. Da je knjiga već bila izišla, smije se pretpostaviti da bi se Pilar po svojem običaju pozvao na nju, kao što će učiniti i u svibnju, kad sastavi novi sličan dokument. ${ }^{27}$ Pojedini elementi iz novopronađene Spomenice sigurno nas upućuju na 1918. godinu. Na primjer, podatci o prevrat-

ich-Ungarn und Polen”, Reichspost (Beč), 15. 1. 1918., 2; „Ungarn und die polnische Frage”, Polen (Beč), 4 (1918), Nr. 166, 8. 3. 1918., 286-287; Julius ANDRÁSSY, „Der Friede im Osten”, Polen, 15. 3. 1918., 308-310; Philip v. LANGENHAHN, „Zur austro-polnischen Lösung”, Polen, 5. 7. 1918., 19-21; Robert SIEGER, „'Austro-polnische Lösung”, Grazer Tagblatt (Graz), 25. 7. 1918., 1-2; „Ungarn und die Polenfrage”, Reichspost, 3. 9. 1918., 1; Edmund v. POLNER, „Die polnische Frage in staatsrechtlicher Beziehung", Polen, 4. 10. 1918., 4-8 i Nr. 197, 11. 10. 1918. 41-49; „Dies irae. Oestrreich und Polen”, Polen, 18. 10. 1918., 68-71 i dr.

24 Vidi: Alfred GÜRTLER, „Südslawenfrage und Dualismus”, Grazer Tagblatt, 17. 3. 1918., 1-2; Robert SIEGER, „Jugoslawisch und grosskroatisch”, Grazer Tagblatt, 19. 3. 1918., 1-2; „Das ungarische Chaos”, Allgemeiner Tiroler Anzeiger (Innsbruck), 29. 4. 1918., 2; Auszug aus der Tagespresse (Beč), 8. 6. 1918., 6; „Dualismus und Subdualismus”, Auszug aus der Tagespresse, 10. 6. 1918., 5; Robert SIEGER, „Die ungarisch-österreichische Monarchie”, Fremden-Blatt, 16. 6. 1918., 3-4; Heinrich FRIEDJUNG, „Die südslawische Frage”, Neues Wiener Tagblatt, 21. 9. 1918., $1-2$ i dr.

25 U članku „Dualizam i trializam” varaždinske Naše pravice, glasilo Hrvatsko-srpske koalicije (5 /1908/, br. 46, str. 7), još 5. studenog 1908. tumačile su kako bi kvadralizam zadovoljio Hrvate i Čehe.

26 Vidi: Denkschrift über die südslavische Frage.

27 Ta pretpostavka - o kojoj će konačnu riječ dati buduća istraživanja - čini se vjerojatnijom nego pomisao da je ovaj Pilarov dokument nastao nekoliko mjeseci poslije, u rujnu 1918. prigodom posjeta grofa Tisze Sarajevu, kad je Pilar predao ugarskome predsjedniku svoju spomenicu. Vidi: JONJIĆ, Ivo Pilar - pisac, političar, ideolog, 734 
ničkoj situaciji u Rusiji, poljskome problemu i o „rastućoj srbofiliji na jugu”. Nadalje, tekst upućuje na okolnosti koje su bile relativno povoljne za položaj Austro-Ugarske, a to je sigurno vezano uz proljetno razdoblje navedene godine. Citiranje „autoriteta” nudi još neke motive u određenome trenutku. Pozivanje na Samassino djelo ide u prilog ocjeni da se Pilar tijekom 1918. nastojao pragmatično osloniti na skupinu njemačkih nacionala (Deutschnationale) koji su se iz svojih razloga, među kojima se najčešće navodi osiguranje pristupa njemačkome čimbeniku do Trsta, sve više bavili južnoslavenskim pitanjem. Podatak o navođenju ideja Karla Rennera govori nam pak o tome da Pilar nije zaobilazio ni djelo prvaka socijalne demokracije i austromarksizma, koji mu je mogao biti blizak zbog prihvaćanja ideja Friedricha Naumanna o Mitteleuropi, kao i težnje da se očuva zemljišni integritet Monarhije.

Datacija drugoga od dvaju dokumenata koje donosimo razmjerno je jednostavna, a budući da se u njemu doslovce nalaze neke iste misli i rečenice koje nalazimo u prvome, logično je pretpostaviti da su oba teksta nastala $\mathrm{u}$ malome vremenskom razmaku. Taj tekst počinje izjavom da su „listovi posljednjih dana sve češće pisali da Bosnu i Hercegovinu treba izravno pripojiti Ugarskoj”. Zatim se navode primjeri iz novina Az Est („od 5. o. m.”) i Vossische Zeitung, koje je moguće identificirati u suvremenom tisku, što znači da je i Pilarov tekst nastao u istome mjesecu, u svibnju 1918. godine. ${ }^{28}$ Podatak se slaže s historiografskom ocjenom da „u proljeće 1918. dolazi u mađarskoj štampi do akcije oko priključenja Bosne i Hercegovine Ugarskoj”. ${ }^{29} \mathrm{~K}$ tome nam $\mathrm{u}$ dataciji dokumenata pomaže još jedan arhivski nalaz. U navedenoj Baernreitherovoj ostavštini ručno je na prvoj stranici Spomenice i Rješenja upisan nadnevak 20. svibnja 1918., gotovo punu godinu od objave Svibanjske deklaracije u Carevinskome vijeću i deset dana prije održavanja poznate sjednice Krunskoga vijeća u Badenu na kojoj je glavna točka dnevnoga reda bilo južnoslavensko pitanje, a prvi se put u raspravu u tome formatu uključio i hrvatski ban Antun pl. Mihalovich. ${ }^{30}$ Ne treba zaobići ni poznatu sjednicu „triju guvernera”, održanu 13. i 14. svibnja 1918. u Sarajevu, gdje se također, na još izravniji način, raspravljalo o raznim aspektima južnoslavenskoga pitanja. Tamo Pilar nije bio spomenut, ali se razgovor vodio o aktualnim temama koje kontekstualiziraju njegove koncepcije. ${ }^{31}$

Iz svih tih okolnosti, kao i iz drugih podataka - kao što su mirovni pregovori u Brest-Litovsku i pozivanje na knjigu Južnoslavensko pitanje i svjetski

28 Auszug aus der Tagespresse, 8. 5. 1918., 5. Ovdje se u rubrici o unutarnjoj politici u Ugarskoj prenosi članak iz Az Esta (Budimpešta) od 5. svibnja 1918. koji se bavi izjavom ugarskoga ministra predsjednika Wekerlea u prilog prijedloga o priključenju Bosne i Hercegovine zemljama krune svetoga Stjepana.

29 KAPIDŽIĆ, Bosna i Hercegovina pod austrougarskom upravom, 243.

30 O toj sjednici vidi: KOMJÁTHY, Protokolle des Gemeinsamen Ministerrates, 661-669.

31 Vidi: STULLI, „Prilozi građi”, 279-335 i ČUTURA, Stjepan Sarkotić, 238-248. O vezama između Sarkotića i Pilara te o sličnostima i razlikama u njihovim političkim pogledima vidi: GRIJAK, Politička djelatnost vrhbosanskog nadbiskupa Josipa Stadlera, 537-538; ČUTURA, Stjepan Sarkotić, 228-229; JONJIĆ, Ivo Pilar - pisac, političar, ideolog, 602-604, 716-720, 730. 
rat - jasno je da je Rješenje nastalo nakon pisanja Spomenice. No sve upućuje na to da oba teksta potječu iz prijelomne 1918. i da ih možemo smjestiti u proljeće te godine, dok je Pilar još vjerovao u ratnu pobjedu Centralnih sila i mogućnost primjene kompromisne formule koja bi ispunila dio hrvatskih nacionalnih ciljeva.

\section{Raščlamba ključnih koncepcija}

\section{Subdualizam i kvadralizam}

Novopronađena Spomenica bavi se rješenjem koje Pilar u postojećim okolnostima smatra „logičnom evolucijom daljnjeg razvitka dualističkog načela". U tom kontekstu pojavljuju se pojmovi subdualizma i kvadralizma, koji su otprije bili u upotrebi kao manje ili više razrađeni modeli nadgradnje trijalističkih koncepcija možebitnoga preuređenja Monarhije koji se javljaju kao specifična zamjena za davne planove o njezinoj federalizaciji koje je moguće pratiti već od prve polovice XIX. stoljeća. Trijalističkim je koncepcijama zamah dala politika kruga oko nadvojvode Franje Ferdinanda koji se obično naziva „velikoaustrijskim”. Ta politika, pojednostavnjeno označena trijalističkom, otvarala je nadu u stvaranje treće ravnopravne jedinice u sastavu Monarhije, pa je na slavenskome Jugu, osobito među Hrvatima, od vremena rasprava o pravnom položaju Bosne i Hercegovine nakon priključenja tih zemalja Austro-Ugarskoj našla znatan broj simpatizera. No slične nade javljale su se i na sjeveru države, među Česima i osobito Poljacima, koji su oživotvorenje trijalističkoga načela priželjkivali u obliku stvaranja slavenske (češke, odnosno poljske) države pod habsburškim žezlom. ${ }^{32}$

Budući da su trijalističke koncepcije nailazile na žestok otpor zagovornika postojećega dualističkog uređenja države, osobito Mađara, a imale su reperkusija i na unutarnjopolitička previranja u Austriji, u kojoj su neke grupacije, poput kršćanskih socijala, pokazivale stanovite simpatije prema takvim zamislima reforme Monarhije, izlaz je tražen u subdualizmu, tj. u osiguranju državnopravnoga položaja manjinskih naroda - a time i jačanju cijele države - unutar jedne od monarhijskih polovica. Zato je u suvremenom novinstvu, pa potom i u historiografiji, subdualizam i prije rata spominjan kao dio raznih strateških kombinacija. O njemu se govorilo kao o jednoj od mogućnosti rješenja hrvatskoga, odnosno južnoslavenskoga pitanja, u formi subdualističkoga povezivanja hrvatskih zemalja s ugarskom ili austrijskom polovicom Monarhije. No i tada je - pored pitanja o mogućoj opstrukciji sa strane nove, tre-

32 O „poljskom trijalizmu” vidi npr.: Mieczyslav SZERER, „Studien zur Bevölkerungslehre Polens”, Polen, 26. 3. 1915., 340-341; Edmund v. POLNER, „Die polnische Frage in staatsrechtlicher Beziehung", Polen, 4. 10. 1918., 4-8 i Nr. 197, 11. 10. 1918., 41-49. O češkim trijalističkim zahtjevima vidi primjerice: Adolf BACHMANN, „Sind die Ausgleichsverhandlungen in Böhmen erfolgsversprechend?", Neue Freie Presse, 28. 6. 1914., 3. 
će jedinice zbog hrvatsko-srpskih opreka - postavljano pitanje kompenzacije druge monarhijske polovice te je nagovješćivano da bi ta formula aktualizirala kvadralističke zahtjeve, $t$. stvaranje usporednoga subdualizma u drugoj polovici države. ${ }^{33} \mathrm{U}$ kasnijoj fazi svjetskoga rata, napose 1918., subdualizam se u novinstvu spominje sve češće, ${ }^{34}$ a s njim se susrećemo i pod pojmom "prikrivenoga trijalizma”, koji bi podrazumijevao da se, opet iz hrvatske perspektive neostvarivosti ustrojavanja treće državne jedinice koja bi imala isti položaj i prava kakva su imale Austrija i Ugarska, pronašao drugačiji model za zadovoljavanje nacionalnih interesa u danim okolnostima. ${ }^{35}$

Model je počivao na pokušaju usklađivanja interesa Poljaka i Hrvata s dualističkom arhitekturom Monarhije, koja je smatrana aksiomom službene politike i u koju u ratno doba, iz razumljivih razloga, nitko nije imao hrabrosti dirati. U tim je koncepcijama subdualizam zamišljen kao mogući izlaz iz slijepe ulice raspravljanja ponajprije s mađarskom stranom. Drugim riječima, tom se koncepcijom svjesno odstupalo od dotadašnjega sporenja s nadmoćnijim Mađarima, kojima je bilo koji oblik federalizacije Monarhije bio neprihvatljiv, da bi se pronašlo „minimalno” rješenje u dualističkom okviru.

Drugim riječima, ni kvadralizam koji Pilar spominje kao mogućnost rješenja hrvatskoga pitanja nije bio njegov izum ni novotarija. Kao što smo vidjeli, on se pod tom oznakom - pa i kao prijetnja da preraste u kvinkvali$z a m$ - pojavljivao i prije Prvoga svjetskog rata. Još je prije zagrebački dnevnik Agramer Zeitung prenio vijesti iz mađarskoga tiska koji je napao vodstvo hrvatske politike, zapravo bana, da je popustljiv prema "trijalističkoj iredenti”, što je navelo „sjeverne Slavene da slijede primjer onih južnih” i time traže "Quadralismus". ${ }^{36}$

Povjesničari smatraju da je iz službenih krugova koncepciju kvadralizma u ljeto 1916. prvi lansirao knez Konrad Hohenlohe, austrijski ministar unutarnjih poslova, koji je držao da bi se Monarhija morala pretvoriti u savez četiriju država, pri čemu bi uz Austriju i Ugarsku bile stvorene poljska jedinica, sastavljena od Galicije, Bukovine i zauzetih dijelova ruske Poljske, te novooblikovana Ilirija, u kojoj bi se nalazile Trojedna Kraljevina i Bosna i Hercegovina, te bi u njezin sastav ušle vojno zauzete Srbija i Crna Gora, a Ri-

33 Usp. članak „Trialismus”, Gottscheer Bote (Kočevje), 19. 9. 1912., 18, koji se bavi razmatranjima Hermanna R. von Monschawa objavljenim u časopisu Österreich-Ungarn. U istom se tekstu pored kvadralizma (Quadralismus) spominje mogućnost da bi kretanje u tom smjeru moglo dovesti i do kvinkvalizma (Quinqualismus) budući da bi Slaveni u Galiciji, odnosno Česi u Češkoj i Moravskoj mogli tražiti priznanje svoje zasebne jedinice. U tom kontekstu valja primijetiti da kvadralističke i kvinkvalističke koncepcije zapravo impostiraju federalizaciju Monarhije u obliku svojevrsne „asimetrične federacije” - termin koji će se u političkom žargonu pojaviti sedamdesetak godina poslije, u vrijeme raspada druge jugoslavenske države.

34 Vidi primjerice: Auszug aus der Tagespresse, 22. 3. 1918., 2; Auszug aus der Tagespresse, 8. 6. 1918., 6 .

35 MATIJEVIĆ, „Državno-pravne koncepcije”, 123.

36 „Die Konferenz der kroatischen Delegation, Budapest, 7. Feber.”, Agramer Zeitung (Zagreb), 7. 2. 1912., 6 . 
jeka bi ostala u sastavu Ugarske. ${ }^{37}$ Svaka jedinica imala bi svoju vladu i parlament, a vojna organizacija, vanjska politika i trgovina bile bi pod ingerencijom središnjega parlamenta i vlade. Taj je plan Hohenlohe izložio i zastupniku u Carevinskom vijeću Vjekoslavu Spinčiću, koji ga je službeno posjetio krajem siječnja 1916. u Beču. Iz toga je moguće da je Pilar o kvadralističkim zamislima bio obaviješten ne samo iz tiska, nego upravo od Spinčića, s kojim je održavao kontakte, premda je očito da njih dvojica tijekom rata nisu imali bliska politička gledišta, napose kad je posrijedi način rješavanja južnoslavenskoga, odnosno hrvatskoga pitanja. ${ }^{38}$

Kvadralizam je ozbiljnije uzeo u razmatranje spomenuti barun Hussarek, predsjednik austrijske vlade od srpnja 1918., u čijoj presloženoj verziji, pored Austrije i Ugarske, ta koncepcija obuhvaća poljsku i hrvatsku jedinicu, čime je donekle u skladu i s Pilarovom Spomenicom. ${ }^{39}$ Slično Pilaru, Hussarek nije mogao računati na promjenu dualističkoga ustroja zbog nepopustljivosti mađarske strane u pogledu revizije ustavnoga uređenja, pa je na kraju ponudio polovična rješenja. Načelno je pristao na poboljšanje poljskoga položaja i složio se s mogućnošću ujedinjenja banske Hrvatske s Dalmacijom te Bosnom i Hercegovinom, ali nije htio raspravljati o pridruživanju Slovenaca nekom obliku ,južnoslavenske jedinice" ${ }^{40} \mathrm{U}$ pogledu zamišljene Ilirije jasno se pokazuje razlika u razmišljanjima između austrijskoga ministra i Pilara. Prvi je bio zagovornik aneksije zauzete Srbije i Crne Gore, a Pilar je bio dosljedan protivnik takva pridruživanja, smatrajući da bi se time ,još pogoršala dosadašnja situacija na Jugu” („die bisherigen Verhältnisse im Süden noch zu verschlechtern"), odnosno da bi okupirana područja mogla biti još desetljećima odvojena pod vojnom upravom („diese Gebiete noch Dezennien separat unter militärischer Verwältung behalten werden"). ${ }^{41}$ U stvarnosti se on tomu protivio zbog uvjerenja da bi se u tom slučaju težište monarhijske istočne politike premjestilo na istok, u Srbiju, a i demografsko-političke posljedice takva priključenja za Hrvate bi bile nepovoljne. ${ }^{42}$ Problem rješavanja statusa Srbije i Crne Gore javljao se i u nekim drugim prijedlozima, pri čemu su obično vojni autoriteti bili skloniji aneksiji, a civilni autori pretežno su zagovarali obnovu predratnih država uz oduzimanje onih prerogativa koji bi mogli štetiti habsburškim interesima.

Pilarova razmatranja kvadralističke formule rješenja hrvatskoga pitanja jasno otkrivaju njegovu svijest o realnoj politici. On time formalno napušta trijalističku koncepciju, koja je bila toliko popularna u dijelu hrvatske politič-

37 RAHTEN, Od Majniške deklaracije do habsburške detronizacije, 128-129 i PLETERSKI, Prvo opredeljenje Slovenaca za Jugoslaviju, 96.

38 O odnosu Spinčića i Pilara vidi: HR-HDA-819, Spinčić V., kut. 2, Dnevnik, 21, podaci za 1916. i 1918., bez paginacije te JONJIĆ, Ivo Pilar - pisac, političar, ideolog, 665.

39 Više o Hussareku u: RUMPLER, Max Hussarek, 95, gdje se spominje i Pilarovo lobiranje za njegov način rješavanja južnoslavenskoga pitanja.

40 KANN, The Multinational Empire, sv. 2, 280.

41 Vidi Prilog 1.

42 JONJIĆ, Ivo Pilar - pisac, političar, ideolog, 571, 582, 639, 691-692. 
ke elite, čak i po cijenu da ga površni promatrači optuže za zagovaranje dualizma. Moguće je da to čini dijelom i zato što trijalizam u ratnim godinama zadobiva novu dimenziju, sve češće se vežući uz rješavanje poljskoga pitanja, čime se ciljalo na „ujedinjenje svih ili većine poljskih zemalja pod Habsburgovcima". ${ }^{43}$ No zacijelo mu je važnija bila činjenica da je trijalizam, onakav kakav je godinama zagovaran iz nekih hrvatskih krugova, nailazio na otpor čak i među Hrvatima, a kamoli ne među Mađarima i austrijskim vladajućim krugovima, kojima je bila neprihvatljiva hrvatska ili južnoslavenska jedinica s osloncem na hrvatsko državno pravo. Prema nekim znakovima, simpatije za te zamisli pokazivao je tek prijestolonasljednik Franjo Ferdinand, koji nije dospio pokazati bi li ih doista proveo u djelo, te dio austrijskih kršćansko-socijalnih krugova i doista malobrojni pojedinci među njemačkim nacionalima koji su shvaćali da je to cijena koju valja platiti za opstanak države. Sve njih je, međutim, zapravo više motivirao otpor prema širenju mađarskoga utjecaja u Monarhiji nego simpatije prema Hrvatima i Slovencima.

Pristajanjem uz subdualističko uređenje Monarhije - odnosno uz njezinu kvadralističku reformu koja uključuje specifičnu inačicu subdualizma kojim se, uz stanovite neizbježne žrtve, osigurava ujedinjenje hrvatskih zemalja i osiguranje njihova autonomnoga položaja (koji bi, prema Pilarovim zamislima, evolutivnim putem jačao) - Pilar je svjesno prihvatio krupan politički rizik. Stvorio je time vlastitu Ahilovu petu jer su ga politički protivnici, ali i mnogi drugi dionici ili promatrači hrvatskih prilika, mogli prikazati, a i prikazivali su ga, jednom kao popustljivca koji uzmiče pred predstavnicima mađarskih državnih interesa i pristaje na nedostojni kompromis kojim i dalje ostavlja hrvatsko/južnoslavensko pitanje pod diktatom Budimpešte, a drugi put kao pouzdanika bečkih i njemačkih krugova za čiji se račun on zalaže za ostanak Istre i slovenskih zemalja pod austrijsko-njemačkom dominacijom. Previđalo se pritom da se on zalaže za osiguranje hrvatskoga položaja, ističući i ovdje (u Rješenju) da je njemu „načelno svejedno, hoće li hrvatsko pitanje biti riješeno u Cislajtaniji ili u Translajtaniji, u dualističkoj, trijalističkoj, kvadrilističkoj ili čak federalističkoj državi”.

Polazište takvih kritičara njegovih pogleda vjerno ilustrira članak iz dobro obaviještenoga, liberalnoga ljubljanskog dnevnika Slovenski narod. U tekstu pod naslovom „Subdualizem” taj je list u prvoj polovici lipnja 1918. prenio članak iz uglednoga Neue Zürcher Zeitunga, koji je izvješćivao o djelovanju „izvjesnih” krugova u Monarhiji koji su nudili rješenje južnoslavenskoga pitanja uz zadržavanje dualističkoga ustava. ${ }^{44} \mathrm{~S}$ obzirom na bitan sadržaj, taj je prijedlog prema svemu sudeći načelno odgovarao glavnini Pilarovih razmišljanja. U njemu se predlaže udruživanje banske („ugarske”) Hrvatske, Dalmacije, Istre i Bosne i Hercegovine u jednu državu koja bi bila spojena s

43 BATOWSKI, „Hrvati i Poljaci”, 447-454.

44 „Subdualizem”, Slovenski narod (Ljubljana), 10. 6. 1918., 1. Na taj se članak pod naslovom „'Subdualističko' vijećanje jugoslavenskog problema” osvrnulo i Novo doba (Split), 13. 6. 1918., 3 . 
Ugarskom. Nova država, koja se spominje pod imenom „ugarske Velike Hrvatske ili srpsko-hrvatske Jugoslavije" ${ }^{35}$, imala bi autonomni status kakav je banska Hrvatska stekla prema Hrvatsko-ugarskoj nagodbi, a članak dalje opisuje kako bi povećanje ugarske polovice i stvaranje nove državne jedinice koja uključuje područja što su do tada bila ili pod njezinom izravnom upravom (Dalmacija i Istra) ili u kondominijskom statusu (Bosna i Hercegovina) kompenzirala austrijska strana Monarhije. Ta bi se naknada sastojala u ostvarenju poljske države, sastavljene od Poljskoga Kraljevstva i Galicije i subdualistički udružene s austrijskom polovicom. Dvije subdualističke tvorevine imale bi svoje parlamente i bile bi ovisno o dualističkoj pripadnosti zastupane u Carevinskom vijeću u Beču ili zajedničkome Ugarsko-hrvatskom saboru u Budimpešti. Na taj bi se način, prema tekstu iz švicarskoga dnevnika, riješio teret jugoslavenskoga i poljskoga narodnog pitanja. U svojem se komentaru Slovenski narod narugao mudrijašima koji takvim pokusima zapravo žele zadržati dualizam i osigurati si kolonijalna područja za gospodarsku ekspanziju. U skladu sa svojim poslanjem, slovenski je dnevnik očekivano osuđivao takav prijedlog u kojem bi se Slovenci našli izvan formule za rješenje hrvatskoga/ jugoslavenskoga pitanja. Opravdanje da moraju biti ispušteni iz subdualističke podjele zbog svojega smještaja na prostoru koji Beč i Austriju povezuje s Trstom i Jadranom nije ih moglo zadovoljiti.

No Pilar od svojih zamisli nije odustajao. Bio je svjestan da nema izgleda za dokinuće dualističkoga ustroja Monarhije tijekom rata, ali je ocjenjivao da bi upravo rat i teritorijalno-politička postignuća Monarhije na sjeveru mogli otvoriti prostor za postavljanje hrvatskoga pitanja na novo i čvrsto polazište. Zato polazi od toga da bi ustrajanje u postojećem ustavno-pravnom ustroju Monarhije značilo žrtvovanje države njezinoj formi. Umjesto toga, on polazi od „zdravog rješenja” reorganizacije države slijedom ustavnoga zakona. „Logička evolucija” vodi ga do uvođenja kvadralizma („Quadralismus”), odnosno do preustroja Austro-Ugarske u faktično četiri državne jedinice, u kojoj bi dvije, Austrija i Ugarska, i dalje imale nešto nadmoćniji položaj, ali bi druge dvije (hrvatska i poljska, s pripojenom Galicijom), svaka u subdualističkoj vezi s jednom od dviju osnovnih jedinica, imale definiran teritorij i preciziran ustavni položaj koji bi im osiguravao opstanak i prosperitet. Što se hrvatske jedinice tiče, Bosna i Hercegovina ujedinila bi se dakle s Hrvatskom-Slavonijom, Dalmacijom i istarskim (kvarnerskim) otocima te bi takva „hrvatska država” („kroatischer Staat”) bila u neposrednom, subdualističkom odnosu prema Ugarskoj.

$\mathrm{Na}$ taj bi se način istodobno riješila dva akutna pitanja Monarhije: poljsko i hrvatsko/južnoslavensko. U idućoj bi fazi trebalo, predlaže Pilar, riješiti češko i slovensko pitanje, a u međuvremenu bi četiri države od kojih bi se Monarhija sastojala svoje zajedničke poslove rješavale u delegacijama koje bi

45 Izraz „srpsko-hrvatska Jugoslavija” vjerojatno proizlazi iz činjenice da se u nekim, pretežno vojnim krugovima razmišljalo o priključenju zapadne Srbije novoj, subdualističkoj jedinici. 
odašiljala svaka od njih, pri čemu bi se ta izaslanstva po svojoj biti približavala svojevrsnomu središnjem parlamentu. ${ }^{46}$ Jasno je dakle zašto Pilar ni u naslovu dokumenta više ne govori o Austro-Ugarskoj, nego novu tvorevinu naziva Habsburškom Monarhijom. Navođenje češkoga i slovenskoga statusa upućuje, za razliku od drugih Pilarovih prijedloga, na to da ipak nije posve zanemario ta dva naroda, kako su mu to zamjerali protivnici. On je ovdje izložio mišljenje da se rješavanje obaju tih pitanja mora odgoditi, smatrajući da ona nisu „sudbinska” poput poljskoga i hrvatskoga/južnoslavenskoga, te da ustrajanje moćnih Nijemaca na zaštiti njihovih ekskluzivnih prava pristupa Jadranu i Jugoistoku stvarno ne dopušta da se u ratnim okolnostima iziđe ususret Česima i Slovencima.

S druge strane, razvoj situacije pokazao je da je došlo do funkcionalnoga povezivanja čeških i slovenskih prvaka iz Carevinskoga vijeća, koji su iskoristili obnovu parlamentarnoga života i carevu opću amnestiju da što aktivnije povedu borbu za svoje nacionalne interese koje Beč nije htio ispuniti, a završna faza procesa raspadanja Monarhije pokazat će da su zamisli njezina spašavanja preuređenjem poput onih kakve je predlagao Ivo Pilar bile odavno zakašnjele.

\section{Južnoslavensko pitanje}

Pojam označen kao južnoslavensko pitanje, vrlo čest osobito nakon austrougarske aneksije Bosne i Hercegovine (1908.), uvelike je prisutan u političkom životu Austro-Ugarske u doba Prvoga svjetskog rata. Pod njim se shvaća problem uređenja odnosa u jugoistočnom dijelu Monarhije, čije je značenje nadilazilo južnoslavensko područje i utjecalo je i na ostatak države. U tom su kompleksu promatrana tri naroda - Hrvati, Srbi i Slovenci - kao skupine s izgrađenim narodnim identitetima, koje u jezičnome smislu povezuje sličan govor, a razlikuje državnopravni položaj, povijesni razvitak i kulturno-gospodarska orijentacija. Bugari, koji su u prijašnjem razdoblju bili smatrani dijelom istoga kompleksa, iz njega su izostavljeni nakon političkih konfrontacija i ratnih sukoba sa Srbijom u drugoj polovici XIX. stoljeća, a napose nakon balkanskih ratova, kad ni bugarska državna politika nije pokazivala zanimanje za južnoslavensko povezivanje.

U kontekstu rasprava o Pilarovim planovima, u prvom nas redu zanima južnoslavensko pitanje u užem smislu, ono koje se vezivalo uz područje Habsburške Monarhije. Ono je u teritorijalnom smislu najčešće obuhvaćalo međusobno upravno-politički nepovezana područja Hrvatske-Slavonije, Dalmacije, Istre, Kranjske, Štajerske, Koruške, Trsta i Bosne i Hercegovine. Težnja za rješavanjem toga problema, odnosno za ujedinjenjem svih tih zemalja, ili bar nekih od njih (hrvatskih na jednoj, a slovenskih na drugoj strani), nije dolazila samo od južnoslavenske (hrvatske i slovenske) elite, nego su ju s raznim

46 Vidi Prilog 1. 
motivima poticali i neki austrougarski političari, vojni stručnjaci i publicisti, koji su tražili rješenje uređenja odnosa u južnim dijelovima Monarhije, najprije radi stabilizacije toga područja i osiguranja državnih interesa, a potom i zbog rješavanja položaja dviju neovisnih južnoslavenskih država, Srbije i Crne Gore. ${ }^{47}$ Njihov međusobni odnos, kao i odnos Monarhije prema njima i njihovoj ulozi u europskoj politici, razmatran je i prije rata, a novu dimenziju on dobiva u vrijeme rata, kad su se ta područja našla pod austrougarskom okupacijom.

Osim geopolitičkih interesa i težnji Monarhije za gospodarskim širenjem na Jugoistoku kao mostu prema istočnom Sredozemlju i Aziji, taj problem dobiva otvoreno novu dimenziju uslijed jačanja političkih procesa koji su se manifestirali u zahtjevu dijela kulturnih i političkih protagonista za ujedinjenje Južnih Slavena bez obzira na postojeće državne granice, tako da se Srbija prometne u Pijemont jugoslavenskoga ujedinjenja. Srpska politička elita i službeni srpski krugovi u tome su uočili priliku da se rat i jugoslavenska ideologija iskoriste za ostvarenje srpskih interesa, odnosno za ispunjenje zavjetne misli o okupljanju svih Srba u okviru jedne države pod vodstvom srpske dinastije. Neosporni uspjesi srpske vojske u balkanskim ratovima, vlastita država i savezništvo s dijelom moćnih velesila koje su zbog vlastitih interesa bile spremne podupirati Srbiju utjecali su na to da srpska strana dobije dominantan položaj u južnoslavenskom pitanju. Drugim riječima, pojam ,južnoslavensko pitanje" na svoj su specifičan način, s različitim pogledima i interesima, koristili praktično svi akteri tadašnjih političkih, diplomatskih i vojnih previranja, i svi su ocjenjivali da upravo ratni rasplet može donijeti njegovo rješenje na način koji oni priželjkuju.

Iz historijske je perspektive jasno da je ideja južnoslavenstva bila zapravo imaginarna formula nastala kao rezultanta niza raznorodnih čimbenika, među kojima su posebno mjesto imale prosvjetiteljske ideje, protuosmanski sentimenti i moderni nacionalni pokreti, kao i idealizirano shvaćanje nacije kao jezične zajednice, te težnje vladajućih bečkih krugova da se zbližavanjem južnoslavenskih naroda olakša upravljanje tim područjem, što je koincidiralo s nastojanjem katoličkih krugova da se podupiranjem južnoslavenske misli Rimu privedu „raskolnici” s istoka. S druge je strane dio društvene elite tih naroda promatrao južnoslavensku ideju kao mehanizam obrane od ekspanzije neslavenskih utjecaja (njemačkoga, talijanskoga i mađarskoga) te potiskivanja osmanske, odnosno turske vladavine na jugoistoku Europe. U takvim okolnostima, na temeljima preporodnoga zanosa iz prve polovice XIX. stoljeća i zamisli Strossmayera odnosno Račkoga iz kasnijih desetljeća, ona je na prijelazu u XX. stoljeće sve više poticala svijest o neupitnim ne samo uzajamnim nego i zajedničkim interesima južnoslavenskih sastavnica. Na hrvatskoj je strani do izbijanja Prvoga svjetskog rata uski dio njezinih protagonista

47 Neki od hrvatskih sudionika rasprava o južnoslavenskome pitanju, poput generala Stjepana Sarkotića, govorili su da austrougarski državni i vojni vrh nastoji pogurati ,jugoslavenski projekt” koji ne odgovara hrvatskim interesima. STULLI, „Prilozi građi”, 300. 
postupno prerastao u pristaše jugoslavenskoga integralizma, a znatan je dio promovirao i vjerovao u mogućnost harmoniziranja svih sastavnica južnoslavenstva. No i dalje je nezanemariv dio hrvatske elite pristajao uz pravašku ideologiju, koja je u svojoj izvornoj formi odbacila postavke jugoslavenskoga programa i otklanjala mogućnost vezivanja s nositeljima srpske državne ideje u raznim njezinim inačicama. Te su inačice bivale to brojnije što je pluralizacija političkoga života, kao sastavni dio modernizacije društva, bila razvijenija. Tako se, primjerice, mogu pratiti modeli jugoslavenstva za koje je okupljanje Južnih Slavena unutar Austro-Ugarske svojevrsna brana srpskom hegemonizmu, potom oni koji su držali da jedino šire okupljanje može pridonijeti redefiniranju ili rušenju starih carstava poput Habsburške Monarhije, odnosno Austro-Ugarske, koja se teško mijenjanju i daleko kaskaju za modernim, nacionalnim zahtjevima, sve do promišljanja nekih pristaša Katoličkoga pokreta da jugoslavenstvo može pridonijeti sjedinjenju Katoličke i pravoslavnih crkava bar na jugoistoku Europe. Ratne su pak prilike u središte pozornosti dovele pitanje može li se položaj Južnih Slavena (Hrvata i Slovenaca, potom i Srba u zemljama u sastavu Monarhije) riješiti unutar habsburškoga okvira, s manjim ili većim modifikacijama državnoga ustroja, ili je taj problem moguće riješiti samo bez obzira na postojeći državni okvir, tj. odcjepljenjem južnoslavenskih zemalja od Austro-Ugarske i stvaranjem nove, južnoslavenske države, bez obzira na to hoće li to ujedno značiti raspad Dvojne Monarhije.

Tim se pitanjem bavi Pilarovo glavno djelo, koje ga sadržava i u naslovu. Kod njega se južnoslavensko pitanje sagledava kroz hrvatski ključ, odnosno za nj se ono svodi na hrvatsko pitanje, pri čemu je on uvjeren da se u zadanim okolnostima ono može, pa zato i treba riješiti samo „pod habsburškim žezlom”. Prvotno odgojen u južnoslavenskome („slavosrpskom”, kako sam kaže) duhu, Pilar se ubrzo po dolasku u Bosnu i Hercegovinu (1900.) suočio sa srpskim („svesrpskim”) imperijalizmom te se zauvijek oslobodio jugoslavenskih sentimenata. Došao je do uvjerenja da Hrvate i Srbe, kao dva ključna nositelja južnoslavenske ideje, dijele različite osobine, tradicije i vjeroispovijesti, a time i različiti, u biti suprotstavljeni interesi budući da, prema njegovu mišljenju, nositelji srpske nacionalne i državne ideje (srpska država, svetosavska crkva te intelektualna i gospodarska elita u zemljama koje se nalaze u sklopu Austro-Ugarske) teže širenju narodnih i državnih granica srpstva, čime se izravno ugrožavaju hrvatska područja i hrvatski interesi. On je bio načistu s time da u stvarnosti srpska politika uspješno ostvaruje svoje nakane. To je samo jednim dijelom pripisivao sposobnostima srpske elite, a s druge strane uzroke tomu vidio je u hrvatskim slabostima te u državnome poretku - poglavito u dualizmu - koji je Hrvate neizbježno stavljao u oporbeni položaj spram obiju monarhijskih polovica te ih na taj način diskreditirao i marginalizirao.

Nije dakle štedio aktere na hrvatskoj sceni, pa je bio kritičan i prema Starčevićevim koncepcijama, a naravno i prema raznim jugoslavenskim strujama u hrvatskoj politici. Istodobno je osuđivao načelno oporbenjaštvo, smatrajući ga neplodnim, pa je s istoga kritičkog motrišta kritizirao i svoje ratne surad- 
nike poput nadbiskupa Stadlera i frankovačke pravaše, što ga je na kraju rata dovelo praktički u izolaciju. No, kao što je spomenuto, intimno - a ponekad ni javno - nije štedio ni glavne državne (austrijske, a pogotovo mađarske) čimbenike, kojima je predbacivao nesposobnost uočavanja i shvaćanja problema koji Monarhiju, a s njom i hrvatski narod, prema njegovu mišljenju, vode u propast. Kritizirajući tu politiku „noja koji zabija glavu u pijesak”, Pilar je dobro shvaćao razne interese koji su ju motivirali. Bilo mu je jasno da povremena spremnost istaknutih političara, pa i samoga vladara, da raspravljaju o južnoslavenskom pitanju ne izvire samo iz težnje za postizanjem unutarnje stabilnosti, nego je istodobno dio vanjskopolitičke koncepcije kojom Monarhija nastoji osigurati prevlast u jugoistočnoj Europi, ujedno i dio međusobnoga austrijsko-mađarskog nadmetanja.

Kao što je u vrijeme austrougarskih vojnih uspjeha bio protiv uključenja okupiranih srpsko-crnogorskih područja u Monarhiju, Pilar je među prvima postao svjestan jugoslavenskih i protumonarhijskih dimenzija Svibanjske deklaracije Jugoslavenskoga kluba (1917.). Glavnina njegovih aktivnosti do kraja rata bit će zapravo upravljena protiv Deklaracije i pokreta koji je ona izazvala. To će ga konfrontirati ne samo s hrvatskim nego i sa slovenskim protagonistima i pristašama toga pokreta pod vodstvom Antona Korošca i Janeza Kreka. Pritom je njihov sraz očitovao koncepcije koje su, sagledavajući genezu problema, ipak imale neke dodirne točke. Prema pojedinim analizama, Krek, koji je umro u listopadu 1917., predlagao je u jednome trenutku da se „buduća jugoslavenska država veže za ugarski dio Monarhije tj. tzv. subdualizam”. ${ }^{48}$ Istodobno su se tvorci Svibanjske deklaracije i Deklaracijskoga pokreta sa središtem u slovenskim zemljama odmaknuli od ideje trijalizma. Iz toga bi proizlazilo da se radilo o koncepcijama koje su imale stanovite poveznice. Pritom je jasno da je Pilar neostvarivom smatrao nadu da bi se slovenske zemlje mogle odvojiti iz austrijskoga dijela i uvrstiti se zajedno s hrvatskim područjima u ugarsku polovicu Monarhije. Dok je kod slovenskih aktera koji su se okretali prema jugoslavenskome pokretu bilo vidljivo da su zaključili kako zbog njemačkoga (odnosno njemačko-austrijskoga) otpora ne mogu riješiti svoj položaj u Austriji, dotle je Pilar - nemajući alternative osim one jugoslavenske - nastavio i dalje vjerovati u strateške veze s Bečom kao čimbenikom koji jedini može pripomoći u otupljivanju mađarskoga ustrajanja u klasičnome dualizmu.

Svjestan da maksimalistički zahtjevi imaju simpatičan odjek u javnosti, ali nemaju izgleda za ostvarenje, Pilar je u svojim prijedlozima pokazivao spremnost žrtvovati Istru (premda je bio itekako svjestan njezina hrvatskoga karaktera), a mađarski pristanak platio bi potpunim odstupanjem Rijeke i povlaštenim željezničkim spojem toga grada s Mađarskom. Sličnu spremnost na žrtvu pokazao je i u pogledu slovenskih zemalja jer je smatrao da ih se austrijsko-njemački krugovi neće odreći iz geostrateških i gospodarskih ra-

48 ZEČEVIĆ, Slovenska ljudska stranka i jugoslovensko ujedinjenje, 55. 
zloga. Te njegove koncepcije osuđivali su mnogi njegovi suvremenici, a nije rijetko nazivan i izdajicom. No to zapravo nije bilo posve neobično u nizu kombinacija iz prijašnjega i ratnoga vremena, kao što rječito pokazuju slovenske kritike obuhvata Novoga kursa i Riječke rezolucije, propitivanja Supilovih strategija o jugoslavenskom pitanju, pa i način raspodjele pozicija u Jugoslavenskome odboru. A da Pilar ipak nije bio posve ravnodušan prema sudbini Slovenaca, pokazuje upravo njegova novootkrivena Spomenica, u kojoj se pri raspravi o južnoslavenskome ne prešućuje ni slovensko pitanje. Očito je da su u njegovim stajalištima Slovenci u etapnom rješavanju promatrani kao dio „južnoslavenskoga posjeda”, ali da ipak imaju ostati dijelom austrijske polovice Monarhije, što se kosilo s naporima Deklaracijskoga pokreta na čelu s Korošcem. Situacija u središtu hrvatske politike toga vremena pokazuje da su o slovenskom položaju slično mislili pristaše frankovačke Stranke prava, koji u svojoj saborskoj adresi nisu zahtijevali ujedinjenje sa Slovencima, ali su izjavili da se položaj susjeda preko Sutle može naknadno formulirati. Vodstvo Hrvatsko-srpske koalicije odbilo je pozive na suradnju s Korošcem, držeći se pravila dualističkoga sustava podjele i ostavljajući time slovenske političare da se snalaze u tadašnjim prilikama Austrije. Jedino je Starčevićeva stranka prava pristala na usuglašenu politiku.

Poseban će slučaj biti s Bosnom i Hercegovinom, gdje je Pilar živio do kraja rata, pa i neko vrijeme nakon toga. Njegov prijedlog o vezivanju toga prostora s Trojednom Kraljevinom sastavni je dio izvornoga političkog programa i strategije Hrvatske narodne zajednice, pa je i sada svakako trebao ići u prilog afirmacije hrvatske nacionalne ideologije čiji su protagonisti te pokrajine smatrali hrvatskim zemljama. Na taj bi se način u Pilarovoj interpretaciji hrvatsko pitanje riješilo u sklopu subdualističkoga rješenja južnoslavenskoga pitanja shvaćenog u širem smislu. Da ne provocira dodatne otpore (ne samo mađarske i srpske, dijelom i austrijske, nego i muslimanske), on, za razliku od većine drugih aktera, u svojim prijedlozima unutarmonarhijskih reformi ne želi dirati postojeće granice Bosne i Hercegovine, pa naglašava da ona „ostaje u sadašnjem obliku” i kao takva pridonosi „ekonomskoj održivosti” subdualističke jedinice. Što je pak o tome doista dugoročno mislio, jasno proizlazi iz njegova ustrajnoga isticanja geopolitičke povezanosti i gospodarske komplementarnosti jadranske obale (Dalmacije) i njezina zaleđa. Time se on, naravno, konfrontira sa srpskom nacionalnom i državnom mišlju, za koju su i okupacija i aneksija nasilnički i protupravni čini. Pilar je u tome vidio veliku opasnost jer je držao da Srbija preko Bosne i Hercegovine želi izići i na Jadran u Dalmaciji. Zato je zagovarao ne samo subdualističko povezivanje nego i stvaranje katoličko-muslimanskoga savezništva kao prepreke velikosrpskim pretenzijama. Njegovo je stajalište, međutim, doživjelo poraz, a on se krajem rata suočio s trijumfom teze o Srbiji koja u hrvatske zemlje dolazi kao „osloboditelj”. 


\section{Poljsko pitanje}

Prvi svjetski rat zaoštrio je više nacionalnih pitanja koja su zadirala u političku strategiju, pa i sam opstanak pojedinih velesila. To je napose vrijedilo za višenacionalne monarhije u oba sukobljena tabora. Novootkriveni Pilarovi dokumenti, osobito njegova dosad nepoznata Spomenica, uz već uobičajeno južnoslavensko pitanje, snažno upozorava na poljski problem, u čijem je korijenu bila činjenica da je nekadašnje veliko poljsko kraljevstvo i dalje bilo raskomadano između Austro-Ugarske, Njemačkoga i Ruskoga Carstva, pa je poljski narod bio bez vlastite države. ${ }^{49}$ Ratna su previranja stvorila priliku da se to izmijeni i da se poljska država obnovi bilo kao neovisna, bilo u obliku određene autonomije koja bi obuhvatila i upravno povezala Poljake. Osim odnosa prema trima spomenutim velesilama, to je otvaralo i pitanje teritorijalnih prijepora sa susjednim narodima, osobito Litavcima i Ukrajincima, koji su u novim okolnostima također otvoreno postavljali zahtjev za vlastitu državu, a i na unutarnjem je planu dovodilo do polarizacije između zagovornika bezuvjetne neovisnosti i pristaša autonomije, među kojima su se rađale razne zamisli o trijalističkim, subdualističkim i kondominijskim rješenjima.

$S$ poljske se strane isticalo da je prusko-njemački i austro-ugarski interes stvoriti snažnu poljsku državu odnosno poljsku jedinicu kao branu prema ruskom imperijalizmu, ${ }^{50}$ a realne okolnosti i pragmatični razlozi sugerirali su povezivanje s višenacionalnom Austro-Ugarskom, koja se činila manjom prijetnjom od nacionalne Njemačke. Zato se često isticalo da personalna unija i autonomija unutar Austro-Ugarske („austro-poljsko” rješenje) nisu negacija težnje za neovisnom poljskom državom ${ }^{51}$ i da Poljska samo u sklopu austro-poljskoga rješenja može dobiti Galiciju. ${ }^{52}$ Protivnici toga modela, koji se pojavljivao u raznim inačicama, tvrdili su međutim da austro-poljsko rješenje nije prihvatljivo i da će ga vrhovi Monarhije odbiti jer bi u suprotnome potaknuli druge Slavene u državi da postave slične zahtjeve. ${ }^{53} \mathrm{~S}$ mađarske strane u tom pogledu nije bilo nikakve dvojbe: sve načelne, a zapravo taktičke simpatije prema poljskim težnjama bile su uvjetovane zahtjevom da se time ne dira u ustroj Monarhije i njezin „dualistički paritetni odnos” (dualistisches Paritätsverhältnis). ${ }^{54}$

49 Za pregled poljske povijesti s naglaskom na situaciju pri kraju Prvoga svjetskog rata vidi: AGIČIĆ, Podijeljena Poljska 1772. - 1918., 111.

50 „Das Bollwerk eines gesicherten Friedens. Eine Rede des Geheimen Rates Dr. v. Jaworski”, Polen, 4. 1. 1918., 12-14; „Nachrichten des Mitteleuropäischen Staatenbundes. Prof. Dr. Neumann-Hofer, Mitglied des Reichstages, über die Polenfrage”, Polen, 20. 9. 1918., 248.

51 „Die österreichisch-polnische Lösung”, Polen, 1. 2. 1918., 118; „Die Polen und die neue Ukraine", Reichspost, 12. 2. 1918., 3.

52 „Die Klubs der nationalen Einheit”, Polen, 8. 2. 1918., 162; „Landestagung der 'Klubs der nationalne Einheit"', Polen, 15. 2. 1918., 185.

53 Usp. kritiku rasprave Adolfa GRABOWSKOGA „Die Krisis der Polenfrage”, Polen, 11. 1. 1918., 54-55.

54 „Die ungarische Delegation und die polnische Frage”, Polen, 4. 1. 1918., 23; „Ungarn und die austro-polnische Lösung", Polen, 20. 9. 1918., 236-237. 
Jasno je da su zbivanja na istočnome bojištu, a onda i ispadanje Rusije iz rata doveli do intenziviranja rasprava o poljskome pitanju u samoj Austro-Ugarskoj. U sklopu te rasprave razmatrano je austro-poljsko rješenje, odnosno razni modeli subdualizma u Cislajtaniji te personalna unija pod habsburškom dinastijom. Beč je bio dodatno potaknut i oružanim angažmanom Poljskih legija na strani Centralnih sila u borbama na istočnoj bojišnici. Galicijski Poljaci tradicionalno su bili lojalni habsburškoj dinastiji. Zauzvrat su neki pripadnici poljske aristokracije obnašali visoke državne funkcije. S druge strane, dio poljske emigracije okupio se u Parizu, gdje su osnovali svoj Odbor, koji je računao na potporu Antante u stvaranju obnovljene Poljske.

$\mathrm{Za}$ hrvatske je političare poljski faktor postao bitna politička činjenica kad su uočili da bi habsburška dinastija mogla Monarhiji priključiti dijelove Poljske koji su se do uspjeha vojske Centralnih sila nalazili pod ruskom upravom (kongresna Poljska). Gledajući iz perspektive unutarnjega preoblikovanja Dvojne Monarhije, otvarala se mogućnost da se usporedno zatraži rješavanje južnoslavenskoga/hrvatskoga i poljskoga pitanja. Uspjesi oružanih snaga Centralnih sila potaknuli su Berlin i Beč da odluče otvoriti poljsko pitanje tako da ostvare svoj utjecaj. Njemački car Vilim II. i Franjo Josip početkom studenoga 1916. objavili su proglas o postanku Poljskoga Kraljevstva na prostoru koji je do tada bio pod ruskom državnom upravom. Uz to je austrougarski vladar odlučio proširiti povlastice za područje Galicije. Taj je čin trebao u potpunosti privući Poljake na stranu Centralnih sila i time osigurati jaku polugu u nadzoru ruskoga protivnika na istočnome bojištu. Međutim, ratna su zbivanja pojačavala osjećaj nestabilnosti i otežavala donošenje odluka.

Smrt Franje Josipa dovela je na prijestolje nedovoljno iskusnoga Karla I. (IV.). Novi se vladar, kako to pokazuju brojni izvori, odmah sučelio s izazovom preispitivanja naslijeđenih odnosa u ratnom vihoru. Treba li postići separatni mir, prekinuti savezništvo $s$ Njemačkom i na taj način pokušati sačuvati Austro-Ugarsku? Interesi vladajućih struktura i nepomirljivi zahtjevi nacionalnih i gospodarskih elita rađali su snažnim otporima, pa se pitanje pokazalo preteškim za mladoga vladara. U pogledu poljskoga pitanja situacija je bila višeslojna. Prva revolucionarna ruska vlada najavljivala je obnovu moći posrnuloga „slavenskog diva”. Pod vodstvom ministra vanjskih poslova Pavla Miljukova Rusija je nastavila zagovarati stare ratne ciljeve, želeći „sjediti za trpezom pobjednika”, ${ }^{55}$ što je jasno govorilo o tome da se ruski geopolitički interesi nisu promijenili slomom carizma. Promjene u Rusiji nagovješćivale su i novi položaj jugoslavenske emigracije i njezinih protuhabsburških ciljeva. Za hrvatske emigrante jugoslavenske orijentacije ruski su događaji značili potvrdu stalnosti ruskih aspiracija, ali i nagovještaj uspostave boljih veza s Jugoslavenskim odborom, odnosno zahlađenje sa srpskom diplomacijom. ${ }^{56}$

55 FAULKNER, Povijest Oktobarske revolucije, 147.

56 MARJANOVIĆ, Londonski ugovor, 411. 
S druge strane, vitalnost i utjecaj Poljskoga nacionalnog komiteta u Parizu nisu bili zanemarivi. Američki predsjednik Woodrow Wilson u svojim je ratnim istupima, među ostalim, nagovijestio „politiku ujedinjene, neovisne i autonomne" Poljske. S nešto kasnijim trijumfom boljševika zapadni su saveznici sve više naglašavali potrebu stvaranja neovisnih država u srednjoj $i$ istočnoj Europi, koje su trebale postati branom širenju komunističke revolucije. U tom su smislu Poljaci is Antantine strane dobili dodatnu potporu, što je u novi položaj stavilo i poljske političke čimbenike unutar Austro-Ugarske, koji u prvim tjednima 1918. poduzimaju niz koraka prema stvaranju državnih institucija, očekujući da će mirovni pregovori s Rusijom okruniti njihova nastojanja. ${ }^{57}$

Takve su okolnosti tjerale habsburškoga vladara na aktivnost. Međutim, izostalo je upravo ono s čime je trebalo što prije izići ususret onim narodima Dvojne Monarhije koji su težili postizanju više državne autonomije. Karlo I. (IV.) na početku vladavine odlučio se na lojalnost starim savezništvima. U unutarnjoj politici ostao je vjeran dualističkom sporazumu s Mađarima položivši prisegu na ugarski ustav u Budimpešti, a u vanjskoj je ostao vjeran savezništvu s carskom Njemačkom. Do kraja 1917. činilo se da je takva orijentacija polučila rezultate jer je talijanska vojska doživjela težak poraz kod Kobarida, a austrougarska okupacijska uprava nadzirala je situaciju u Srbiji, Crnoj Gori i dijelu Rumunjske. Jedna od posljedica vojnih uspjeha bilo je i jačanje predodžbe o djelotvornosti dualističkoga mehanizma u kojemu su presudnu riječ imali austro-njemački i mađarski političari.

No ti uspjesi i solidan geostrateški položaj Monarhije nisu doveli do njezine trajnije konsolidacije. Više je razloga utjecalo na izbijanje nove krize, koja je na kraju bila fatalna za habsburšku dinastiju i državu. Sve raširenija pojava gladi u pojedinim dijelovima Austro-Ugarske počela je iznutra slabiti državni aparat i potkopavati povjerenje pučanstva. To se nije moglo kompenzirati naizgled povoljnim vanjskopolitičkim perspektivama jer su i one ustvari nosile neuklonjivu klicu poraza. Činilo se da Wilsonova politika ne ide za razbijanjem Monarhije, a Beč je s članicama Antante vodio tajne razgovore o separatnome miru. Oktobarska revolucija činila se dobitkom koji omogućava izbacivanje Rusije iz rata i mogućnost usredotočenja na druge fronte.

No, iza toga privida nazirao se dramatičan rasplet. Načelo samoodređenja naroda pokrenulo je u Monarhiji unutarnje borbe koje su se sve više zaoštravale jer austrougarski vrh nije htio o tome raspravljati, odgađajući rješenja za poslijeratno vrijeme. Pokušaji zapadnih sila da tajnim pregovorima slome Waffenbrüderschaft između Austro-Ugarske i Njemačke nisu urodili plodom, nego su, naprotiv, u zemljama članicama Antante ubrzali odluku da Monarhiju ipak treba razbiti. Pregovori u Brest-Litovsku pokazali su da austrougarska vlada više nije kadra pronaći kompromis u zastupanju raznih interesa svojih

${ }^{57}$ „Das Gesetz betreffend den polnischen Staatsrat”, Neue Freie Presse, 10. 2. 1918., 7; „Die provisorische Verfassung Polens. Der Uebergang bis zur Schaffung des Landtages”, Reichspost, 10. 2. 1918., 6; „Das Gesetz über den Staatsrat”, Polen, 15. 2. 1918., 174-176. 
naroda. ${ }^{58}$ Otklanjanje njihova zahtjeva da sudjeluju u pregovorima o miru na istočnoj fronti Poljaci su doživjeli kao težak udarac. ${ }^{59}$ Pojava gladi i potrebe za hranom išla je u prilog priznavanju Ukrajinske Republike, koja je 9. veljače 1918. sklopila mir s Centralnim silama. Taj je čin odmah izazvao duboko nezadovoljstvo Poljaka, koji su morali promatrati kako se područje Holma odvaja i priključuje novoj Ukrajini. ${ }^{60}$

Kako je u pretežnom dijelu poljske javnosti vladalo uvjerenje da najnoviji događaji znače „,̌etvrtu podjelu Poljske”, ${ }^{11}$ Poljski klub u Carevinskom vijeću prešao je u oporbu. ${ }^{62}$ Ogorčenje je raslo tim više što su Ukrajinci zahtijevali da im se osigura posebna krunska zemlja unutar Monarhije koju bi činile istočna Galicija i sjeverna Bukovina. Time su Poljaci od bitnoga saveznika Austrije postali kritičarima nove podjele, kojoj se smisao, prema njihovu mišljenju, svodio na davanje teritorijalnih ustupaka Ukrajincima. Njihovi politički predstavnici okrenuli su leđa austrijskoj vladi, a glavni smjer poljske nacionalne politike počeo se sve čvršće vezivati uz Antantu. Takav je ishod djelovao i na pad povjerenja drugih naroda u Monarhiji koji su očekivali pozitivne promjene. Demonstrativno učvršćivanje austrougarskih veza s Njemačkom nakon afere Sixta Burbonskoga i slavodobitna izjava mađarskoga ministra predsjednika Sándora Wekerlea da je upletanje vanjskopolitičkih problema na bazi nacionalnoga pitanja pokazatelj destabilizacije unutarnje strukture Monarhije jasno su pokazivali da je epizoda s mirom u Brest-Litovsku bila Pirova pobjeda.

Pilar je već dulje vrijeme smatrao da su poljsko i južnoslavensko pitanje dva „najvažnija vanjska i domaća politička pitanja Monarhije”. ${ }^{63}$ Usprkos teritorijalnoj odijeljenosti, ona su međusobno povezana zbog čvrstoga dualističkog ustroja Monarhije, ili, kako Pilar bilježi, „među njima postoji prirodna poveznica” („ein natürlicher Junktim”). Oba ta pitanja, tumači on dalje, trebaju biti riješena isključivo u okviru Habsburške Monarhije. Pritom Pilar smatra da bi za Poljake, uzimajući u obzir i Poljsko Kraljevstvo, najbolje bilo prihvatiti austro-poljsko rješenje jer bi samo na taj način mogli izbjeći terete njemačkoga i ruskoga pritiska. Prednosti Austro-Ugarske on je vidio u zaštiti tradicijskih vrijednosti i činjenici „da Monarhija nije bila nacionalna država nego država narodnosti” („kein Nationalstaat sondern ein Nationalitätenstaat”), odnosno višenacionalna država. Sugerirajući time da je u takvoj državi nemoguća do-

58 WARGELIN, „A High Price for Bread”, 758.

59 „Erklärung der polnischen Regierung”, Polen, 8. 2. 1918., 137-140; „Polen und die Friedensverhandlungen”, Polen, 8. 2. 1918., 159.

60 „Vor neuen Problemen”, Polen, 15. 2. 1918., 169-171; M. F., „Die Chelmer Frage. Von einem polnischen Historiker", Neues Wiener Journal. Mittagsblatt (Beč), 19. 9. 1918., 3-4.

61 „Die Obmannswahl im Wiener Polenklub”, Polen, 22. 2. 1918., 215; „Der Druckfehler als - Staatsmann”, Polen, 4 (1918), Nr. 164, 22. 2. 1918., 222; „Eine neue Teilung Polens”, Polen, 1. 3. 1918., 264-268.

62 „Opposition des Polenklubs!”, Reichspost, 11. 2. 1918., 4; „Die österreichische Krise und der Polenklub”, Polen, 15. 2. 1918., 176-181.

${ }^{63}$ Pilar je još prije zapisao da Hrvati i Poljaci imaju ,jaku situaciju u Monarhiji” koja nudi „novu orientaciju za buduću politiku”. Dr. JURIČIĆ [PILAR], Svjetski rat i Hrvati, 41. 
minacija jednoga elementa i da upravo višenacionalna struktura jamči zaštitu i malih i nejakih, Pilar je u novome ruhu obnovio staru poruku o Habsburškoj Monarhiji kao zaštitnici srednjoeuropskih naroda. Sklon geopolitičkim razmatranjima, naglasio je i bitnost položaja Galicije za obranu i austrijskoga i ugarskoga dijela Monarhije, oprezno tumačeći da je propadanje Rusije samo trenutačno i da strateška promišljanja traže osiguravanje Panonske nizine. Konačno, Pilar upozorava na to da bi pogrešni koraci austrougarskih državnika prema Poljacima mogli i taj narod pretvoriti u iredentistički čimbenik, tako da oni ne bi ostali skloni Centralnim silama, nego bi se okrenuli Rusiji i zapadnim članicama Antante. Stoga je izlaz vidio u austro-poljskom rješenju, koje bi ujedno značilo i uklanjanje dotadašnjega tipa dualizma u Monarhiji („kruti dualistički princip”). Na kraju bi se, usporednim rješavanjem hrvatskoga pitanja, došlo do kvadralizma.

\section{Zaključak}

Tijekom Prvoga svjetskog rata Ivo Pilar izradio je i predstavio više političkih dokumenata. U to su vrijeme posvuda kolali brojni planovi, memorandumi, nacrti i izjave u kojima su iznošeni pojedini koncepti i nuđena rješenja za brojna nacionalna pitanja. Ona su bila uočljiva prije rata, a tijekom njega su zaoštrena zbog mogućnosti da se razriješe na različite načine. Brojnost izvora, u koje treba uvrstiti i dva novootkrivena dokumenta, pokazatelj je Pilarove spremnosti za političku akciju, kao i ilustracija njegova očekivanja da će Austro-Ugarska preživjeti rat, a njezino vodstvo prilikom prijelaza u mirno razdoblje shvatiti potrebu promjene dualističke strukture države da bi osiguralo njezin opstanak i budućnost. Podrobnija analiza pokazuje da su njegovi prijedlozi nalazili put do bitnih čimbenika austrijske politike, čime je bila potvrđena njihova relevantnost u očima dijela nositelja političke moći. Novi dokumenti potvrđuju Pilarov osjećaj za praćenje utjecaja zbivanja na široj sceni i namjeru da se oni iskoriste za promicanje prijedloga o subdualizmu i kvadralizmu u korist hrvatskih nacionalnih interesa kako ih je on zamišljao u kontekstu ratnih previranja. Nadolazeći problemi u novostvorenoj jugoslavenskoj kraljevini iznova su aktualizirali poglede na autora koji je predvidio novi val udara na hrvatski položaj u još drastičnijim oblicima, i to iz niza razloga koje je objasnio u Južnoslavenskome pitanju. 


\section{Prilozi $^{64}$}

1. Denkschrift über die Neuordnung der Habsburgischen Monarchie

Die fürchterliche Heimsuchung des noch immer tobenden Weltkrieges hat einerseits das politische Denken mächtig angeregt, anderseits in der habsburgischen Monarchie das tiefe Sehnen gezeitigt, eine bessere staatsrechtliche Ordnung zu schaffen, welche jene Momente, welche 1908.-1914. ${ }^{65}$ zum Kriege drängten, auszuschalten und auch die während des Krieges in der Monarchie zu Tage getretenen krankhaften Erscheinungen zur Gesundung bringen sollte.-

Eines ist sicher: die gegenwärtigen staatsrechtlichen Einrichtungen können unverändert nicht bestehen bleiben, denn dies liesse alle Krankheitserscheinungen, welche zum Kriege getrieben haben, auch weiter bestehen zu lassen.- Dies wäre einfach ein selbstmörderisches Beginnen. Aber auch ein zweites ist sicher: Grundstürzende Umwandlungen können nach dem Kriege in der Monarchie nicht platzgreifen.- Schon deshalb, weil die bestehende Staatsordnung der ungeheuren Belastung des Weltkrieges dennoch standgehalten hat.- Ferner desshalb [deshalb], weil zu tiefgreifende Veränderungen den Staat inneren Erschütterungen aussetzen würde[n], welche bei den wenig konsolidierten internationalen Verhältnissen nach dem Kriege die Monarchie weitgehenden Gefahren aussetzen würden.

Zwischen diesen zwei Polen, einer kühnen, weitausgreifenden Neuerungssuch und einem furchtsamen Konservativismus schwanken die verschiedenen Faktoren der Monarchie. Sicher ist nur eines: sollte die Pendel der Entscheidung zu nahe einem der Pole stehen bleiben, so wird eine Gesundung der Monarchie nicht erreicht werden können.-

Festzustellen, wo die goldene Mitte liegt von welcher eine gesunde Weiterentwicklung der altehrwürdigen Habsburgischen Monarchie gewährleistet wäre, dies ist leider noch niemanden gelungen.- Die Schicksalschwere der Frage hat vielmehr zur Folge, dass man sich mit konkreten Plänen gar nicht hervorwagt. Dies ist aber ein grosser Nachteil, denn die wichtigste Lebensfrage der Monarchie kann aus einen Urnebelzustande nicht herauskommen.

Es sei daher gestattet, im nachfolgenden einen konkreten Vorschlag zur Staatsrechtlichen Neuordnung der Habsburgischen Monarchie zu formulieren.-

Die führenden Gedanken des Gefertigten sind:

1./ die ausser- und innerpolitisch wichtigsten Fragen der Monarchie, welche dieser Krieg aufgeworfen hat, dass man ihnen nicht ausweichen kann, sind die polnische und die südslavische, d. i. die kroatische Frage; keine dieser

64 Priređivači su iz izvornoga teksta uklonili očigledne pisarske pogreške, ali nisu dirali u arhaične ili nepravilne oblike za kojima je autor posegnuo.

${ }_{65}$ Razdoblje obilježeno aneksijom Bosne i Hercegovine i izbijanjem Prvoga svjetskog rata. 
beiden Fragen kann ohne Rücksichtnahme auf die andere gelöst werden; es besteht ein natürliches Junktim unter denselben.

2./ Der Dualismus kann in der bisherigen starren Form nicht fortbestehen, zunächst darum, weil er eine befriedigende Lösung der beiden Vorgenannten Lebensfrage der Monarchie einfach ausschliesst;

3./ Eine gesunde Lösung der Neuordnung in der Monarchie kann nur in einer logischen Evolution einer Weiterentwicklung des dualistischen Prinzips bestehen.-

Wir wollen nun die einzelnen angeführten Punkte eingehender behandeln und darstellen:

ad 1./ Es erübrigt sich zu beweisen, dass die polnische und die südslavische d. i. die kroatische Frage, die wichtigsten Fragen der Monarchie sind. Dies empfindet wohl ein jeder politisch denkende Mensch in der Monarchie.Es soll aber nachgewiesen werden, dass sie beide geradezu Schicksalsfragen der Monarchie sind.

2/ Ich bin der Ansicht, dass die polnische Frage nur im Ramen [Rahmen] der Habsburgischen Monarchie gelöst werden kann und darf.- Der neuentstehende Staat Polen kann zwischen die viel grösseren staatlichen Einheiten Deutschland, Oesterreich-Ungarn und Russland /ganz einerlei, welche endgültige Form das einstige Reich dieses Namens annimmt/ eingekeilt, ein gedeihliches selbstständiges Leben nicht führen.- Seine natürliche Stellung ist in Oesterreich-Ungarn schon desshalb, weil von allen in Betracht kommenden Mächten die historischen Traditionen zu der Monarchie die stärksten sind, weil nur die Monarchie kein Nationalstaat sondern ein Nationalitätenstaat ist, welcher naturgemäss der neuen polnischen Einheit die besten Lebensbedingungen bieten kann, was auch darin zu ersehen ist, dass es gerade in Oesterreich-Ungarn den Polen bisher am besten gegangen ist.-

Ich verfechte auch die Ansicht, dass auch vom Gesichtspunkte der Monarchie nur eine austro-polnische Lösung zugelassen werden darf.- Es handelt sich um Galizien. Ich glaube, dass Oesterreich-Ungarn Galizien absolut nicht herausgeben kann, u. zw. nicht so sehr aus wirtschaftlichen, als aus militärisch-strategischen Gründen. Galizien ist ein unentbehrliches strategisches Verteidigunsvorfeld der seit jeher von allen Erobern stark begehrten Pannonischen Ebene. Dass mit dem jetzigen Zusammenbruch Russlands alle Gefahren von Nordosten für alle Zeit verschwunden sind, wird wohl nur ein politisches Kind glauben können.- Von diesem Gesichtspunkte ist aber Galizien nicht nur für Oesterreich sondern vornehmlich für Ungarn von allergrösster Wichtigkeit.-

Polen kann aber auf Galizien ebenfalls nicht verzichten.- Kommt es nicht in den Ramen der Gesammtmonarchie [Gesamtmonarchie], so wird es Galizien nicht erhalten.- Die Monarchie bekommt eine neue Irredenta und einen neuen Feind. Dies wäre auch vom Gesichtspunkte der Weltgeschichte ein grosses Unglück, denn meiner Ueberzeugung nach, wäre damit die Stellung- 
nahme Polens gegen die Zentralmächte festgelegt, und müsste Polen demzufolge seine Anlehnung an Russland und die Westmächte suchen.-

Meiner Auffassung nach kann dieser unvermeidlichen Entwickelung [Entwicklung] nur durch eine befriedigende austropolnische Lösung der Frage vorgebeugt werden. Dadurch wäre auch die Schicksalsschwere und die Wichtigkeit dieser Frage genügend gekennzeichnet.-

b/ Nicht minder wichtig ist die Südslavische Frage. Die Wichtigkeit dieser Frage ist am besten dadurch gekennzeichnet, dass gerade aus ihr seit der Jahrhundertwende sämmtliche [sämtliche] schwere Krisen für die Monarchie und schliesslich auch der Weltkrieg entsprossen ist.-

Doch ist der letzte Grund, warum der Weltkrieg gerade aus der südslavischen Frage entstehen musste, nicht genügend erfasst noch bekannt. Die Sache liegt in Folgendem: 1867. als der Einheitsstaat Oesterreich in zwei Staaten, Oesterreich und Ungarn, getrennt wurde, wurden auch die kroatischen Länder geteilt, Ungarn bekam Kroatien-Slavonien, Oesterreich hingegen Dalmatien. Dadurch wurden die Kroaten in's Mark getroffen und erlitten eine politische capitis deminutio maxima, ${ }^{66}$ denn sie wurden hüben und drüben zu einer solchen Minorität herabgedrückt, dass sie politisch nicht zur Geltung kommen könnten. Die kroatischen nationalen und historischen Rechte auf Dalmatien kamen jedoch trotzdem in kroatisch-ungarischen Ausgleiche /:Ges. Art XXX ex 1868, \$ 65 und 66: $/{ }^{67}$ soweit zum Vorschein, dass Dalmatien als gesetzlich zu Kroatien-Slavonien daher auch zu den Ländern der heil. Stephanskorne gehörend bezeichnet wurde. So kam die ganz mögliche staatsrechtliche Lage zu Stande, nach österreichischen aber zu Oesterreich gehörte. Aber der dualistische Gesammtstaat hatte ein Interesse daran, dass am der 1867. geschaffenen Ordnung nicht gerüttelt werde.- So kam die noch unmöglichere Tatsache zu Stande, dass die Kroaten, indem sie das ihnen staatsrechtlich gewährleistete Recht der Inkorporierung Dalmatiens verlangten, die Interessen des Gesammtstaates und der bestehenden Staatsordnung bedrohten.-

Die notwendige Folge davon war, dass die Kroaten sich seit 1867. in einem ständigen und unheilbaren Konflikt mit der Staatsmacht befanden, dass seit 1867. stets gegen die Kroaten regiert wurde und werden musste und dass der Staat in dieser Lage der Meinung war, sich stets auf die natürlichen Feinde des kroatischen Volkes stützen zu müssen.- So wurden die Serben und die Italiener natürliche Verbündete des dualistischen Staates.- Man übersah aber vollkommen, dass diese Feinde der Kroaten zugleich natürliche Feinde des Gesammtstaates seien. So hat der Staat von 1867.-1914. seine eigenen Fein-

66 Capitis deminutio (lat.) - u rimskome pravu gubitak jednoga od triju statusa rimskoga građanina (status libertatis, status civitatis, status familiae). Capitis deminutio maxima označuje gubitak stati libertatis, odnosno gubitak slobode i prelazak u položaj roba, čime se automatski gube i preostala dva statusa (ROMAC, Rječnik rimskog prava, 49).

67 Prema ovim nagodbenim (zakonskim) člancima, Kraljevina Ugarska priznaje zemljišnu cjelovitost kraljevina Hrvatske i Slavonije te se obvezuje da će na temelju prava sv. ugarske krune zahtijevati da im se Dalmacija pridruži. 
de grossgezogen, sie durch ständige und ununterbrochene Teilnahme an der Macht erstarken bzw. sich das Leben verlängern lassen, und hat dies in seiner Verblendung so lange getan, bis die künstlich grossgezogenen Serben und Italiener in diesem Griege [Kriege] unternahmen, dem Staate die kroatischen Länder einfach wegzunehmen.-

Dies ist aber nicht das einzige Unheil.- Diese Politik des Ausspielens der offenbaren Staatsfeinde gegen begründete, ja legale Ansprüche der Kroaten hat bewirkt, dass die staatstreuen Kroaten den Glauben an den Staat verloren, im steigenden Maasse [Masse] von staatsgefährlichen Tendenzen ergriffen werden, weil sie sich im Bestreben, diesem Ausspielen ein Ende zu setzen, ihrerseits den Serben und Italienern zu nähern trachten.- Dies ist der letzte Grund der sogen. nationalen Einheit der Kroaten und Serben und der steigenden Serbophilie im Süden. So führt diese unheilbringenden Politik seit 1867. dazu, dass die Staatsfeinde im steigenden Maasse ein bisher mit Recht als verlässlich geltendes Volk gegen den Staat auszuspielen vermögen.-

Aus diesem schwer kranken Millieu entstand und musste der Weltkrieg entstehen, und es werden und müssen immer neue Krisen für den Staat entstehen, insolange die Ursachen des Unheils, welche in der Teilung der kroatischen Länder, im unmöglichen Schwerbezustande Dalmatiens und der Kroatenfeindlichen Politik der Monarchie im Süden nicht dauernd beseitigt werden.-

Dies kann nur durch Vereinigung der von altersher kroatischen Länder Kroatiens, Slavonien, Dalmatiens und Bosnies und der Herzegovina zu einem einheitlichen Verwaltungsgebiet unter der Herrschaft der Kroaten, welche ohnedies die zahlenmässige Mehrheit haben. /2,800.000 Katholiken und 600.000 Moslemische Kroaten, - 3,200.000 ${ }^{68}$ Kroaten gegen 1,500.000 Orthodoxe Serben/ erreicht werden. ${ }^{-69}$

Seit langem sind sich die besten Männer des Staates bewusst, dass die südslavische Frage nur durch die Bildung eines südslavischen Staaten zu lösen sei. Dieser Staat kann aber aus historischen, aus staatspolitischen und bevölkerungsstatistischen Gründen nur ein kroatischer sein, es kann nur ein katholisch-muselmanisches Königreich Kroatien sein.-

Hiebei [Hierbei] betone [betonne] ich, dass ich von einer Vereinigung eventuell zu erwerbender [erwerbenden] serbischen Gebiete mit dem bisherigen kroatischen Besitze der Monarchie unbedingt absehe. Dafür sind viele

68 Ovaj je zbroj pogrešan jer bi trebao iznositi 3.400 .000 ako se polazi od toga da Pilar sve muslimane smatra Hrvatima.

${ }^{69}$ Ove brojke otprilike odgovaraju posljednjem statističkom popisu stanovništva uoči rata, a Pilar ih preuzima iz Ungarisches Statistisches Jahrbuch za 1913. i Oesterreichs statistisches Handbuch für die im Reichsrate vertretenen Königreiche und Länder za istu godinu. Međutim, Pilar malo odstupa od brojki koje je iznio u izvornom izdanju Južnoslavenskoga pitanja (str. 585), gdje je naveo da postavlja hrvatsku skupinu na sljedeći način: u Dalmaciji 500.000, u Hrvatskoj i Slavoniji 1.750.000, katolika u Bosni i Hercegovini 400.000, a muslimana 600.000. Uz njih još navodi 200.000 u Istri, 300.000 u Ugarskoj i 500.000 u prekooceanskom iseljeništvu. 
Gründe vorhanden, deren vornehmlichster darin besteht, dass eine Vereinigung in der Praxis bedeuten würde die Gährungsvorgänge aus den neuerworbenen Gebieten Serbiens auch in den bisherigen Besitz zu tragen, und die bisherigen Verhältnisse im Süden noch zu verschlechtern.- Sollten wir serbische Gebiete erwerben, was Gefertigter jedenfalls für einen sehr zweifelhaften Gewinn ansieht, so müssten diese Gebiete noch Dezennien separat unter militärischer Verwaltung behalten werden, denn man muss mit ständigen Zettelungen und Aufständen rechnen.- Die Emigration und diverse feindliche ausländische Einflüsse werden dafür schon sorgen.-

ad 2./ Der Dualismus kann in seiner bisherigen Form desshalb nicht fortbestehen, weil weder die polnische noch die kroatische /:südslavische:/ Frage bei seinem Fortbestande gedeihlich gelöst werden kann. Das Festhalten an der unveränderten bisherigen Form würde daher ein Versagen des Staates seinen Pflichten auf Selbsterhaltung und gedeihliche Fortentwickelung bedeuten, und würde ohnedies früher oder später zu einem Bruche, der als verderblich erkannten Staatsform, führen müssen.-

a/ Das Königreich Polen kann eine österreichische Provinz nicht werden. Erstens desshalb, weil es die Polen nicht wollen, und dies auch keine Lösung der polnischen Frage darstellte, welche wohl nur in der Erneuerung des polnischen Staates ihre Lösung finden kann.

Auch glaube ich, dass eine solche Lösung weder den Deutschen Oesterreichs noch Oesterreich selbst genehm sein kann. Die Deutschen können [kämen?] in einen Minorität, was ihren Bestrebungen der letzten Jahrzehnte / Linzer Programm ${ }^{70} /$ diametral zuwiederliefe [zuwiderliefe]. Aber auch von allgemein Oesterreichischischen Gesichtspunkte wäre eine solche Lösung nicht wünschenswert. Das geographisch-politisch uneinheitliche, und ungünstig configurierte Oesterreich bekäme im äussersten Nordosten eine starke Vergrösserung, was seine innere Uneinheitlichkeit nur noch vergrössern würde, und das Schwergewicht der Oesterreichischen Staatshälfe in einer ungesunden excentrischen Richtung verschieben würde.-

Ich glaube daher feststellen zu dürfen, dass eine solche austropolnische Lösung unmöglich ist.

b/ Aber auch eine Lösung der kroatischen /südslavischen/ Frage ist im Ramen des starren Dualismus unmöglich.-

Dies wird im selben Momente offensichtlich, in welchem wir zur Erkenntnis gelangen, dass die 1867. vorgenommene Teilung der kroatischen Länder die Urquelle allen Unheils im Süden sei, und dass sie eigentlich einer Teilung Polens gleichkommt, welche, ebenso wie die Vorgenannte, früher oder später gutgemacht werden muss.-

${ }^{70}$ Lincerski program iz 1882., poznat kao program njemačkih nacionala, odražavao je gledišta austrijskih Nijemaca i njime se tražila veća povezanost Austrije s Njemačkom. Radi suzbijanja slavenske ideje njemački nacionali prihvaćali su i mogućnost odustajanja od nekih zemalja, među kojima i od Dalmacije. Usp. i: SÜDLAND [PILAR], Južnoslavensko pitanje, 363. 
Sobald wir zur Ueberzeugung gelangen, dass im Süden eine Vereinigung der jetzt bestehenden Provinzen erfolgen muss, welche derzeit teils Oesterreich, teils Ungarn gehören, teils wieder beiden Staaten gemeinsam sind, da erscheint sofort die Hauptschwierigkeit der Lösung dieser Frage, wie soll denn diese neue Gebiet in die bestehenden Struktur der Monarchie eingegliedert werden. Bei der Beibehaltung des starren dualistischen Prinzips könnte das neue Einheitsgebiet entweder zur Gänze Oesterreich oder zur Gänze Ungarn zufallen.-

Nun ist es aber klar, dass weder Ungarn auf seine Besitzrechte auf Kroatien, Slavonien und seine Mitbesitzrechte auf Bosnien und Herzegovina zu Gunsten Oesterreichs, noch Oesterreich auf seine Besitzrechte auf Dalmatien und seine Mitbesitzrechte auf Bosnien und Herzegovina zu Gunsten Ungarns verzichten wird.- Dies ist schon desshalb unmöglich, weil dadurch nicht nur das Kräftegleichgewicht zum Nachteile des Verzichtenden Staates erheblich gestört wäre, derselbe verlöre auch die unmittelbaren territoriale Berührung mit dem Balkan und damit die Landverkerhsmöglichkeit mit dem Orient.-

Somit ist also die Lösung der kroatischen Frage im Ramen des dualistischen Staates unmöglich geworden.- Man hat leider 1867. eine Situation geschaffen aus der man nicht hinaus kann. Dies ist auch das Hauptmoment, warum man die kroatische Frage nicht schon eher lösen konnte, und es auf den Weltkrieg ankommen lassen musste.-

Daraus ergiebt [ergibt] sich klar der logische Schluss in der bisherigen starr dualistischen Form kann die habsburgische Monarchie nicht fortbestehen. Denn eine Form welche den Staat hindert, seine wichtigsten und dringendsten Aufgaben zu lösen, hat sich überlebt. Daran festzuhalten hiesse: Der Staatsform den Staat selbst zu opfern.

ad 3./ Trotz alledem ist Gefertigter überzeugt, dass wie Eingangs dargelegt, eine grundstürzende Aenderung nach dem Kriege ausgeschlossen erscheint.- Die Weiterentwicklung kann nur im Wege einer Evolution aus dem bestehenden dualistischen System vor sich gehen.-

Um die Möglichkeiten dieser Weiterentwicklungen zu erfassen, müssen wir den Grundgedanken des Dualismus erfassen.- Wir wollen namentlich zwei Autoren, welche als Autoritäten auf diesem Gebiete gelten: Dr. Springer ${ }^{71}$ /: Karl Renner:/ und Prof Paul Samassa ${ }^{72}$ nennen. Erstgenannter stellt den „leitenden Grundgedanken” der dualistischen Staatsordnung folgendermassen dar: „Der berühmte Gesetzartikel XII. ${ }^{73}$ aus den Jahre 1867. ist die Kodifikation der......neuen, der Osterreichisch-Ungarischen Reichsidee. Der leitende Grundgedanke ist: Von den zehn Völkern der Monarchie sind zwei souve-

${ }^{71}$ Karl Renner koristio je pseudonim Rudolf Springer. Ovdje Pilar navodi njegovu knjigu Grundlagen und Entwicklungsziele der Oesterreichisch-ungarischen Monarchie. Politische Studie (Beč, 1906.).

72 Ovdje Pilar navodi njegovu knjigu Der Völkerstreit im Habsburgerstaat (Leipzig, 1910.).

73 Ugarski je sabor izglasao Austro-ugarsku nagodbu kao Zakonski članak XII. godine 1867. 
rän und reichsunmittelbar, die Deutschen und die Magyaren. Beide gliedern sich je ein halbsouveränes, reichsunmittelbares Volk an: die Deutschen geben den Polen /Sprachenverordnung von 1869/ relative Autonomie, die Magyaren den Kroaten /Ausgleich von 1868/.“ Im Wesen ganz identisch äusserst [äussert] sich Samassa, welcher meint: „Der Sinn des Ausgleiches von Jahre 1867. ist es gewesen, den Deutschen in Oesterreich, den Magyaren in Ungarn die Vorherrschaft zu verschaffen, die Deutschen sollten Polen, die Magyaren die Kroaten zum Teil zur Mitherrschaft heranziehen."74

Man sieht also, die Lebensfragen der zwei mitherrschenden, reichsunmittelbaren Völker der Polen und Kroaten sind diejenigen Fragen, welche der Weltkrieg der Habsburgischen Monarchie aufwarf, sind die polnische und kroatische /südslavische/ Frage.-

Es ist genügend dargetan worden, dass diese beiden Fragen nur durch Schaffung von zweien an die Monarchie untrennbar angegliederten Staaten gelöste werden kann.-

Die Weiterentwicklung des Dualismus muss daher darin bestehen, dass nachdem das Jahr 1867. den beiden Hauptvölkern der Monarchie ihre Staatlichkeit im Ramen des Dualismus auch die beiden reichsunmittelbaren Völker, die Polen und die Kroaten ihren Staat erhalten, und der Dualismus sich zu einem Quadralismus evolutioniert Oesterreich und Ungarn wären die zwei Mutterstaaten an welche sich nun weiter der polnische und kroatische Staat anzugliedern hätten.-

Das Territorium des Königreiches Polen bestände aus dem befreiten Russisch-Polen ${ }^{75}$ nebst Galizien, welche zu einem [einer] territorialen und staatlichen Einheit verbunden würden. Das Königreich Kroatien bestände hingegen aus Kroatien, Slavonien, Dalmatien, Bosnien, der Hercegovina und den Istrianischen Inseln Veglia ${ }^{76}$, Cherse $^{77}$ und Lussin ${ }^{78}$, ohne welche die kroatische Küste verkehrstechnisch wertlos ist.-

Gemäss den Interessen, welche beide Staaten an den Gebieten der beiden neuen Staaten haben, sollte jedoch jeder der beiden neuen Staaten mit beiden Mutterstaaten in ein unmittelbares Verhältnis treten, etwa in der Art, dass ebenso das Königreich Polen wie das Königreich Kroatien mit Oesterreich und Ungarn ein mit den Inhalte des Ausgleichsgesetzes ges. Artikel XII. aus den Jahre 1867. identischen oder ähnlichen Staatsvertrag abschliesst.-

Die Gemeinsamen Angelegenheiten würden in einer Delegation verhandelt werden, welche sich jedoch dem Wesen eines Centralparlamentes nähern müssten. Das heutige Wesen der Delegationen ist ohnehin als unhaltbar erkannt worden.-

74 Pilar u Južnoslavenskom pitanju (hrvatsko izdanje) donosi isti navod na str. 233.

75 Kongresna Poljska, odnosno dio poljske države koji je od 1815. bio pod ruskim nadzorom.

76 Krk.

77 Cres.

78 Lošinj. 
Dieser Art wäre allerdings eine sehr wichtige Frage der Monarchie, die tschechische Frage nicht gelöst. Doch reicht dieselbe, da sie eine überwiegend innerpolitische Frage der Monarchie ist, als Wichtigkeit und Schicksalsfrage and die Polnische und Kroatische /südslavische/ Frage, welche zugleich eine bedeutungsvolle ausserpolitische Folie haben, nicht heran. Ferner ist es zweifelhaft, ob momentan ein günstiger Moment für die Lösung dieser Frage ist. Schliesslich ist dies eine Frage, welche mehr die Deutschen als die Gesammtmonarchie betrifft es ist daher für Aussenstehende um so schwerer, in dieser Frage mit Lösungsvorschlagen hervorzutreten. Aehnliches gilt auch für die slovenische Frage.

Jedenfalls würden durch die von uns beregte Neuordnung die zwei wichtigsten Fragen der Monarchie befriedigend gelöst werden.- Es geschähe dies im Wege einer Evolution aus dem bestehenden dualistischen Prinzipe, dessen Grundgedanken dadurch nicht wesentlich alteriert wären.- Die Monarchie beträte damit auch einen Weg, auf dem sie mit der Zeit auch die anderen, im Laufe der Zeit und in Würdigung der zu Tage getretenen Kräfte unvermeidlich werdenden Fragen lösen könnte ohne an prinzipielle Schwierigkeiten zu stossen.-

Verschmähen die leitenden Kreise der Monarchie diesen Weg, welchen dem Gefertigten als der einzige Ausweg aus der jetzigen [jetztigen] unhaltbaren Situation erscheint, und überwiegen auch nach diesem Kriege engbrüstiger Konservativismus oder Unnachgiebigkeit und Machtgier einzelner Beati possidentes ${ }^{79}$ in der Monarchie, und würde dieselbe bei der Lösung ihrer wichtigsten Frage versagen, so wäre dann früher oder später ein Mene tekel ${ }^{80}$ der Geschichte über einen solchen Staat nicht zu vermeiden.

\section{Die Loesung der suedslavischen Frage}

Die Blättermeldung der letzten Tage bringen immer häufiger die Meldung, dass Bosnien und die Herzegovina direkt an Ungarn angegliedert werden sollen.- Wir weisen hiebei [hierbei] an die sensationelle Nachricht des „As Est" vom 5. d. M. sowie die Wiederholung dieser Nachricht von Seiten der "Vossischen Zeitung” usw. ${ }^{-81}$

Jedenfalls ist die Frage so wichtig, dass es der Mühe lohnt ihr einige Aufmerksamkeit zu widmen.

Es ist vorauszusenden dass Gefertigter ein Anhänger der Lösung der südslavischen, dass ist im erster Reihe der kroatischen Frage ausschliesslich im Ramen [Rahmen] der Habsburgischen Monarchie ist, und dass es ihm

79 Lat. blagoslovljeni oni koji posjeduju. Izrazom se označuje jači položaj posjednika u vlasničkoj parnici.

80 Izraz iz Staroga zavjeta koji označava upozorenje o skoroj propasti. Radi se o dijelu iz proročke knjige Danielove $(5,25)$ u kojemu je Bog navijestio propast babilonskome kralju Baltazaru i podjelu njegova kraljevstva između Medijaca i Perzijanaca.

81 Vidi: Auszug aus der Tagespresse, 8. 5. 1918., 5. 
prinzipiell ganz gleichgiltig ist, ob die Frage im Cis oder Trans, im dualistischen, trialistischen, quadrilistischen oder gar federalistischen Staate gelöst wird. Gefertiger ist nur überzeugt, dass die Lösung dieser Frage eine unaufschiebbare Staatsnotwendigkeit ist, und dass nur jene Lösung eine glückliche ist, welche eine mittlere Linie zwischen den Interessen der Gesammtmonarchie [Gesamtmonarchie] und des Kroatischen Volkes darstellt. Von diesem Gesichtspunkte ausgehend hätte Gefertiger prinzipiell auch nichts einzuwenden, wenn die kroatische Frage im Ramen der Länder der hl. Ungarischen Krone gelöst würde. Doch kann nicht verschwiegen werden, dass Gefertigter gegen diese einseitige Lösung schwere Bedenken hegt.- Es ist sehr fraglich ob es ein Interesse der Gesammtmonarchie ist, dass die österreichische Reichshälfte vom südslavischen Besitze, ausser Slovenen, ganz ausgeschlossen werde und dass die kroatischen Länder welche schon Napoleon als die vor den Toren Wiens aufgestellte Wache bezeichnete, ${ }^{82}$ ausschliesslich ungarischem Einflusse unterstellt würden. Dadurch würde Oesterreich nicht nur den unmittelbaren Kontakt mit dem Balkan und mit dem Orient verlieren, sondern es wäre eine unverhältnissmässige Erstarkung Ungarns herbeigeführt. Dabei wäre aber Oesterreich, da gerade die kroatischen Länder den gefährdesten Punkt der Gesammtmonarchie sind, trotzdem ständig verhalten für eine Politik aufzukommen, auf welche man eigentlich keine unmittelbare Einflussnahme hat. Die bisherigen Erfolge der ungarischen Politik im Süden sind aber nicht solche, um die Oesterreicher diesbezüglich zu beruhigen.-

Obwalten gegen die Lösung der kroatischen Frage im Ramen der Länder der Sct. Stephanskrone an und für sich nicht geringe Bedenken, so muss namentlich an die Gefährlichkeit jener Lösung hingewiesen werden, welche derzeit in Ungarn der offizielle Regierungsplan zu sein scheint. Es ist dies der sogenannte Khuen Hederwarysche Entwurf, welcher einerseits die Inkorporierung Dalmatiens an Kroatien-Slavonien, anderseits aber eine unmittelbare Angliederung eines autonomen Bosnien und der Hercegovina an Ungarn vorsieht. Dieser Entwurf wurde vom Grafen Khuen Hedervary namentlich im Pester Lloyd dargelegt. Aus der Rede des ung. Ministerpräsidenten Weckerle scheint dies als der offiziell von der ungarischen Regierung recipierte Lösungsplan der südslavischen Frage ${ }^{83}$ angesehen werden.-

Diese Lösung muss als ganz unannehmbar und für den Gesammtstaat geradezu als verderblich bezeichnet werden.-

Um diese Behauptung auch gehörig erweisen zu können, müssen wir vorerst darlegen, warum denn eigentlich sämmtliche [sämtliche] schwere Krisen seit der Jahrhundertwende und schliesslich auch der Weltkrieg gerade aus der südslavischen Frage entstanden sind, und entstehen mussten. Leider ist der letzte Grund, warum dies alles so kommen musste, weder erfasst noch genügend bekannt.-

82 Riječ „bezeichnete” upisana je naknadno rukom.

83 Riječ „Frage” upisana je naknadno rukom. 
Die Sache liegt in Folgenden: Im Jahre 1867. als der Einheitsstaat Oesterreich im zwei Staaten, Oesterreich und Ungarn getrennt wurde, wurden auch die kroatischen Länder geteilt, Ungarn bekam Kroatien-Slavonien, Oesterreich hingegen Dalmatien. Dadurch wurden die Kroatien in's Mark getroffen und erlitten eine politische capitis deminutio maxima, denn sie wurden hüben und drüben zu einer solchen Minorität herabgedrückt, dass die politisch nicht zur Geltung kommen könnten. Die kroatischen nationalen und historischen Rechte auf Dalmatien kamen jedoch trotzdem in kroatischungarischen Ausgleiche /Ges. Art. XXX ex 1868, \$ 65 und 66/ soweit zum Vorschein, dass Dalmatien als gesetzlich zu Kroatien-Slavonien daher auch zu den Ländern der hl. Stephanskrone gehörend bezeichnet wurde. So kam die ganz unmögliche staatsrechtliche Lage zu Stande, dass Dalmatien nach ungarischen Staatsrechte zu Ungarn nach österreichischen aber zu Oesterreich gehörte. Aber der dualistische Gesammtstaat hatte ein Interesse daran, dass an der 1867. geschaffenen Ordnung nicht gerüttelt werde.- So kam die noch unmöglichere Tatsache zu Stande, dass die Kroaten, indem sie das ihnen staatsrechtlich gewährleistete Recht der Inkorporierung Dalmatiens verlangten, die Interessen des Gesammtstaates und der bestehenden Staatsordnung bedrohten.-

Die notwendige Folge davon war, dass die Kroaten sich seit 1867. in einem ständigen und unheilbaren Konflikt mit der Staatsmacht befanden, dass seit 1867. stets gegen die Kroaten regiert wurde und werden musste, und dass der Staat in dieser Lage der Meinung war, sich stets auf die natürlichen Feinde des kroatischen Volkes stützen zu müssen. So wurden die Serben und die Italiener natürliche Verbündete des dualistischen Staates. Man übersah aber vollkommen, dass diese Feinde der Kroaten zugleich natürliche Feinde des Gesammtstaates seien. So hat der Staat vom 1867.-1914. seine eigenen Feinde grossgezogen, sie durch ständige und ununterbrochene Teil-nahme [Teilnahme] an der Macht erstarken bzw. sich das Leben verlängern lassen, und hat dies in seiner Verblendung so lange getan, bis die künstlich grossgezogenen Serben und Italianer in diesem Kriege unternahmen, dem Staate die kroatischen Länder einfach wegzunehmen.-

Dies ist aber nicht das einzige Unheil. Diese Politik des Ausspielens der offenbaren Staatsfeinde gegen begründete, ja legale Ansprüche der Kroaten hat bewirkt, dass die Staatstreuen Kroaten den den Glauben an den Staat verloren, im steigenden Masse von staatsgefährlichen Tendenzen ergriffen werden, weil sie sich im Bestreben, diesem Ausspielen ein Ende zu setzen, ihrerseits den Serben und Italiener zu nähern trachten.- Diese ist der letzte Grund der sogen. nationalen Einheit der Kroaten und Serben und der steigenden Serbophilie im Süden. So führt diese unheilbringende Politik seit 1867. dazu, dass die Staatsfeinde im steigenden Masse ein bisher mit Recht als verlässlich geltendes Volk gegen den Staat auszuspielen vermögen.-

Verschlechtert wurde die Situation noch dadurch, dass die einzelnen kroatischen Länder Kroatien, Slavonien, Dalmatien, Bosnien und die Hercegovi- 
na in der jetztigen Form wirtschaftlich absolut lebensunfähig sind. Dalmatien bedarf zu seiner gedeihlichen Entwickelung [Entwicklung] Bosniens und der Hercegovina, seitens natürlichen Hinterlandes und die letztgenannten Länder können sich auch nicht entwickeln ohne ihre natürliche Küste, dies ist eben Dalmatien, Kroatien und Slavoniens natürlicher Zug geht über Bosnien und Hercegovina zum Meere, während es jetzt durch die Centralisierende Bahnpolitik Ungarns nach der entgegengesetzten Seite gezogen wird. So sehen wir, dass Kroatien, Slavonien, Dalmatien seit 1867. wirtschaftlich verfallen, und auch Bosnien und Herzegovina beginnen nach den anfänglichen wirtschaftlichen Aufblühen während der ersten zwei Dezennien, welche auf den segensreichen Einfluss der geordneten Oesterreichisch-ungarischen Verwaltung zurückzuführen ist, eine stagnierende Tendenz aufzuwiesen, welche sich mit der Zeit und bei fortbestehenden politischen Trennung von Dalmatien in einer ausgesprochenen wirtschaftlichen Rückschau [?] ausarten muss.-

So verschlechterte die wirtschaftlich sinkende und stagnierende Tendenz unserer Provinzen in Süden noch die politisch kranke Situation, umsomehr als sie von den freien Balkanstaaten wirtschaftlich überholt wurden.-

So wurde durch diese Sachlage erzielt, dass sich der Staat der seit 1860. andringenden grosserbischen Bewegung im Süden nicht entgegenstemmen konnte. Der Staat war durch die 1867. geschaffene Lage an die Unterstützung der Serben angewiesen, denn das Stützen an die Kroaten würde ja die Inkorporation Dalmatiens, daher die Störung des 1867. erzielten Gleichgewichtes im dualistischen Staate bedeuten. Der Staat musste daher die Serben gewähren lassen, musste vor den Gefahren, welche ihr Erstarken für den Staat bedeutet, die Augen schliessen und eine Vogelstrausspolitik treiben, und dies gieng [ging] so lange bis der Schwarze Sonntag am 28. Juni $1914 .^{84}$ dem Fasse den Boden ausschlug. Wir hatten uns endlich den Weltkrieg eingewirtschaftet.-

Ganz die nämliche Situation soll nun durch den geplanten, direkten Anschluss Bosniens und der Herzegovina an Ungarn neuerdings hergestellt werden.-

Eine zweite Teilung der kroatischen Länder soll wieder durchgeführt werden. Erstens werden die wirtschaftlichen Schäden durch diese Neuordnung nicht behoben, die Länder werden wieder der ungarischen centralisierenden Bahnpolitik unterworfen werden und die Folgen dieser und der bekannten ungarischen Verelendungspolitik werden wieder als politisches Gift krankheitserzeugend werden. Anderseits werden sich dadurch in erster Reihe die Kroaten betroffen fühlen, welche anstatt der Verbesserung ihrer Lage nach dem Kriege, und den Beweisen ihrer Staatstreue sowie grossen Opfern, nun wieder eine Verschlechterung ihrer Situation erfahren.-

Verhältnissmässig am zufriedensten werden damit die Serben sein. Seit Jahren haben sie die Autonomie Bosniens auf ihre Fahnen geschrieben. Die leitende Idee dieser Forderung ist das Bestreben die relative Mehrheit der $43 \%$

84 Datum Sarajevskoga atentata. 
ihrer Bevölkerung in Bosnien und der Hercegovina zur endgültigen Eroberung dieser Länder auszuwerten. Sie befürchten daher nichts mehr als eine Vereinigung Bosniens und der Hercegovina mit Kroatien, Slavonien und Dalmatien, den dadurch würden sie gegen die katholischen Kroaten in eine Minorität gelangen und den grosserbischen Aspirationen wäre für immer eine Riegel vorgeschoben. Von diesem konfessionellen Standpunkte heraus haben auch die Russen stets die Autonomie Bosniens gefordert, selbst bei den Friedensverhandlungen von Brest-Litovsk wurde diese Forderung gestellt.-

Dieser von unseren Feinde stets hartnäckig geforderte Programmpunkt wird nun von der Ungarischen Regierung zum offiziellen Programm erhoben, und von Oesterreich acceptiert.-

Die Folge von alledem wird sein, dass die Serben wieder die notwendige Stütze der ungarischen Herrschaft im Süden sein werden, und die staatstreuen Kroaten wieder an die Wand gedrückt werden. Mit anderen Worten die Serben werden sich wieder mit Hilfe der Staatsmacht auf die Kosten der Kroaten ausbreiten, und es wird wieder derselbe Prozess, welcher vor dem Kriege vor sich gieng [ging], und unaufhaltsam krankheitserzeugend im Süden wirkte, platzgreifen.-

Dabei ist nicht zu übersehen, dass die Ungarn seit jeher mit den Serben mehr sympathisierten als mit den Kroaten. Dies beruht erstens auf dem Umstande, dass die Ungarn ursprünglich ein orientalisches Nomadvolk, eine angeboren grössere Wahlverwandschaft zu den orientalischen Serben als zu den occidentalen Kroaten aufweisen. Bedeutet doch dies eine von den zwei herrschenden Ideen in Ungarn, von der Labanzen- und Kurutzenidee die letztere, welche regelmässig die stärkere zu sein pflegt, einen offenkundigen Anschluss an den Orient.-

Dies wird den Ungarn umsomehr convenieren, als sie in den Serben immer hilfsbereiche [hilfsbereite?] Kämpfer, nicht nur gegen die Kroaten, sondern auch gegen Oesterreich und das Deutschtum finden werden. /:vgl. die Krise im Jahre 1905. die ungarisch-serbische Verbrüderung, und den Friedjung-Artikel in der N. Fr. Presse vom 24. März $1909 . / 85$ und so wird dann diese Neuordnung im Süden wieder ein gemeinsames Vorgehen der Ungarn und Serben gegen die Kroaten bedeuten.-

Die neue Situation wird daher ein gemeinsames Vorgehen der Ungarn und Serben gegen die Kroaten bedeuten, welchen nichts übrig bleibt als der Magyarisierung durch eine Serbisierung vorzubeugen, eine Erscheinung welche wir jetzt schon im Süden sehen.-

Die Serben werden den Ungarn solange dienen, bis sie die Folgen des Weltkrieges überwinden und genügend erstarken um einen neuerlichen Angriff an die Monarchie wagen zu können. Bis dahin werden die verzweifelten Kroaten von den verbündeten Magyaren und Serben dahingebracht: werden,

${ }_{85}$ Radi se o dnevniku Neue Freie Presse od 25. ožujka 1909. (br. 16018, str. 2-4), u kojem je objavljen Friedjungov članak „Oesterreich-Ungarn und Serbien”. 
dass sie mit den Serben gegen den Staat gehen. Denn was sollen sich die Kroaten von der Monarchie denken? Diesen Krieg hat sich die Monarchie eingewirtschaftet indem sie durch fünfzig Jahre die Staatgefährlichen Serben gegen die treuen Kroaten unterstützte. Nun ist der Krieg noch nicht vorbei, in welchen die Kroaten dem Staate helfen, die Folgen dieser gegen sie gerichteten Politik zu überwinden, und den Staat schafft wieder eine Situation in welcher er den sich auf die Staatsfeinde gegen die Kroaten wird stützen müssen.- So muss dann früher oder später der Moment kommen, wo sich der ganze Kompleks im Süden von der Monarchie ablöst, und die Entwickelung in Italien, auf welche die Serben so gerne hinweisen, wiederholt.-

Das geschichtliche Material, welches die obangeführten Ausführungen wissenschaftlich exakt nachweisst [nachweist], ist in dem neusten grossangelegten Werke: die Südslavische Frage und der Weltkrieg von L. v. Südland, Wien, 1917 [1918!], Manzverlag, enthalten. ${ }^{-86}$

Man wird der Monarchie den Vorwurf nicht ersparen können, dass sie beharrlich an eigenem Verderben gearbeitet hat.

${ }^{86}$ Ovdje se navodi godina kad je Pilar dovršio svoju knjigu, koja je, prema svim dostupnim podatcima, objavljena u ožujku 1918. u Beču. Iz ove se pogreške možda može zaključiti da je rukopis nakladniku predan 1917., što nije samo tehničko pitanje budući da sama knjiga sadržava konkretan Pilarov prijedlog za preuređenje Monarhije i rješenje hrvatskoga pitanja. 


\section{Arhivski neobjavljeni izvori}

AT-OeStA-AVA, Riedl: Austrija, Österreichisches Staatsarchiv, Allgemeines Verwaltungsarchiv, Beč, Nachlässe AN Riedl 72.2.

AT-OeStA-HHStA, Baernreither: Austrija, Österreichisches Staatsarchiv, Haus-, Hof- und Staatsarchiv, Beč, SB NL Baernreither.

HR-HDA-819, Spinčić V.: Hrvatska, Hrvatski državni arhiv, Zagreb, fond 819, Spinčić Vjekoslav.

NSK R: Hrvatska, Nacionalna i sveučilišna knjižnica, Zagreb, Zbirka rukopisa i starih knjiga.

\section{Objavljeni izvori i tisak}

Denkschrift über die südslavische Frage (28. 7. 1917.). NSK R 5708. Objavljeno u: Pilar. Croatian Journal of Social Sciences and Humanities 1 (2006), br. 2: 118-124.

FELLNER, Fritz. ur. Das politische Tagebuch Josef Redlich 1908-1919, sv. 2. Graz; Köln: Böhlau, 1954.

KOMJÁTHY, Miklós, ur. Protokolle des Gemeinsamen Ministerrates der Österreichisch-Ungarischen Monarchie (1914-1918). Budimpešta: Akadémiai Kiadó, 1966.

Promemoria über die Lösung der südslavischen Frage (25. 3. 1916.). NSK R $5704 \mathrm{a}$ i b. Objavljeno u: Pilar. Croatian Journal of Social Sciences and Humanities 1 (2006), br. 2: 111-117.

STULLI, Bernard. „Prilozi građi za historiju jugoslavenskog pitanja 1918. godine". Arhivski vjesnik 2 (1959), br. 2: 279-335.

Agramer Zeitung (Zagreb), 1912.

Allgemeiner Tiroler Anzeiger (Innsbruck), 1918.

Auszug aus der Tagespresse (Beč), 1918.

Fremden-Blatt (Karlovy Vary), 1917-1918.

Gottscheer Bote (Kočevje), 1912.

Grazer Tagblatt (Graz), 1918.

Innsbrucker Nachrichten (Innsbruck), 1917-1918.

Naše pravice (Varaždin), 1908.

Neue Freie Presse (Beč), 1909, 1914, 1918.

Neues Wiener Journal. Mittagsblatt (Beč), 1918.

Neues Wiener Tagblatt (Beč), 1918.

Novo doba (Split), 1918.

Pester Lloyd. Abendblatt (Budimpešta), 1918.

Polen (Beč), 1915, 1918. 
Reichspost (Beč), 1918.

Slovenski narod (Ljubljana), 1918.

\section{Literatura}

AGIČIĆ, Damir. Podijeljena Poljska 1772. - 1918. Zagreb: Srednja Europa, 2004.

BATOWSKI, Henryk. „Hrvati i Poljaci u okviru Austro-Ugarske Monarhije (Promatranja i usporedbe)". Historijski zbornik. Šidakov zbornik 29-30 (1976-77): 447-454.

ČUTURA, Dinko. Stjepan Sarkotić - posljednji zemaljski poglavar Bosne i Hercegovine. Zagreb: AGM, 2019.

DANZER, Carl M. Das neue Österreich. Eine politische Rundfrage. Wien: Verlagsbuchhandlung Carl Konegen, 1908.

ĐAKOVIĆ, Luka. Položaj Bosne i Hercegovine u austrougarskim koncepcijama rješenja jugoslovenskog pitanja 1914-1918. Tuzla: Univerzal, 1981.

FAULKNER, Neil. Povijest Oktobarske revolucije. Prev. Iva Karabaić. Zagreb: Fraktura, 2017.

FILEK-WITTINGHAUSEN, Werner. „Riedl, Richard”. U: Österreichisches Biographisches Lexikon, 1815-1950, sv. 9. Beč: Österreichische Akademie der Wissenschaften, 1985, 143.

GRIJAK, Zoran. Politička djelatnost vrhbosanskog nadbiskupa Josipa Stadlera. Zagreb; Sarajevo: Hrvatski institut za povijest; Dom i svijet; Vrhbosanska nadbiskupija, 2001.

JONJIĆ, Tomislav. „Ivo Pilar kao politički ideolog”. Doktorska disertacija, Sveučilište u Zagrebu, 2015.

JONJIĆ, Tomislav. Ivo Pilar - pisac, političar, ideolog (1898. - 1918.). Zagreb: AGM, 2020.

Dr. JURIČIĆ [PILAR, Ivo]. Svjetski rat i Hrvati. Pokus orientacije hrvatskoga naroda još prije svršetka rata. Zagreb, 1915.

KANN, Robert A. The Multinational Empire. Nationalism and National Reform in the Habsburg Monarchy 1848-1918, sv. 2. New York: Columbia University Press, 1950.

KAPIDŽIĆ, Hamdija. Bosna i Hercegovina pod austrougarskom upravom. Sarajevo: Svjetlost, 1968.

KAPIDŽIĆ, Hamdija. „Dva priloga novijoj istoriji Bosne i Hercegovine”. Glasnik arhiva i Društva arhivista Bosne i Hercegovine 2 (1962), knj. 2: 293 328.

MARJANOVIĆ, Milan. Londonski ugovor iz godine 1915. Zagreb: Jugoslavenska akademija znanosti i umjetnosti, 1960.

MATIJEVIĆ, Zlatko. „Državno-pravne koncepcije dr. Ive Pilara i vrhbosanskog nadbiskupa dr. Josipa Stadlera. Od Promemorije do Izjave klerikalne 
grupe bosansko-hercegovačkih katolika”. Godišnjak Pilar 1 (2001), br. 1: 117131.

MATKOVIĆ, Stjepan. „Je li Ivo Pilar bio pravaš?”. U: Pravaštvo u hrvatskome političkom i kulturnom životu u sučelju dvaju stoljeća. Zbornik radova s međunarodnoga znanstvenog skupa, 24. i 25. studenoga 2011., ur. Zdravka Jelaska Marijan i Zlatko Matijević. Zagreb: Hrvatski institut za povijest, 2013, 387-427.

PILAR, Ivo. „Entwicklungsgang der Rezeption des österreichischen allgemeinen bürgerlichen Gesetzbuches in Bosnien und der Herzegowina unter besonderer Berücksichtigung des Immobilienrechtes”. U: Festschrift zur Jahrhundertfeier des Allgemeinen Bürgerlichen Gesetzbuches. 1. Juni 1911, knj. 1. Wien: Manzsche k. u. k. Hof-, Verlags- u. Universitäts-Buchhandlung, 1911, 703-726 [objavljeno i u: Pilar: časopis za društvene $i$ humanističke studije 7 (2012), br. 13 (1): 127-148].

PLETERSKI, Janko. Prvo opredeljenje Slovenaca za Jugoslaviju. Beograd: Nolit, 1976.

RAHTEN, Andrej. Od Majniške deklaracije do habsburške detronizacije. Celje; Ljubljana: Celjska Mohorjeva družba, 2016.

ROMAC, Ante. Rječnik rimskog prava. Zagreb: Pravni fakultet, 1983.

RUMPLER, Helmut. Max Hussarek. Nationalitäten und Nationalitätenpolitik in Österreich im Sommer des Jahres 1918. Graz; Köln: Böhlau, 1965.

SÜDLAND, L. v. [PILAR, Ivo]. Južnoslavensko pitanje. Prikaz cjelokupnog pitanja. Zagreb: Matica hrvatska, 1943.

WARGELIN, Clifford F. „A High Price for Bread: The First Treaty of Brest-Litovsk and the Break-up of Austria-Hungary, 1917-1918”. The International History Review 19 (1997), br. 4: 757-788.

ZEČEVIĆ, Momčilo. Slovenska ljudska stranka i jugoslovensko ujedinjenje 1917-1921. Beograd: Institut za savremenu istoriju, 1973. 


\section{SUMMARY}

\section{Two Unknown Documents of Ivo Pilar from World War I}

During World War I, Ivo Pilar, a famous Croatian politician from Bosnia and Herzegovina, produced and presented numerous political documents. His basic views on the national question are known from pre-war times. In the harsher wartime conditions, they became an example of advocating the resolution of the position of Croatia exclusively within the frame of the Habsburg Monarchy. This text analyses two newly-discovered documents that confirm Pilar's political activities and his expectation that Austria-Hungary would survive the war, while its leadership would come to understand the need to change the dualistic structure of the state in order to secure its survival and future. Analysis shows that his proposals reached the important factors of Austrian politics, which confirms their relevance. The new documents show Pilar's intent that they should be used to promote proposals on sub-dualism and quadrialism in favour of Croatian national interests as he imagined them in the context of the wartime turmoil.

Key words: World War I; Croatian politics; Austria-Hungary; South Slavic Question; sub-dualism; quadrialism 